\title{
REVIEWING THE EFFECTIVENESS OF HERITAGE PROPERTY TAX RELIEF PROGRAMS \\ IN ONTARIO
}

\author{
by \\ Aaron Ryan Cameron \\ Honors Bachelor of Arts, University of Toronto, 2012 \\ A Major Research Paper \\ presented to Ryerson University \\ in partial fulfillment of the requirements for the degree of \\ Master of Planning \\ in \\ Urban Development
}

Toronto, Ontario, Canada, 2014

(C) Aaron Ryan Cameron 2014 


\section{Author's Declaration}

I hereby declare that I am the sole author of this major research paper. This is a true copy of the major research paper, including any required final revisions, as accepted by my examiners.

I authorize Ryerson University to lend this major research paper to other institutions or individuals for the purpose of scholarly research.

I further authorize Ryerson University to reproduce this major research paper by photocopying or by other means, in total or in part, at the request of other institutions or individuals for the purpose of scholarly research.

I understand that my major research paper may be made electronically available to the public. 


\title{
REVIEWING THE EFFECTIVENESS OF HERITAGE PROPERTY TAX RELIEF PROGRAMS IN ONTARIO
}

\author{
(C) Aaron Ryan Cameron, 2014 \\ Master of Planning \\ In \\ Urban Development \\ Ryerson University
}

\begin{abstract}
This paper focuses on heritage conservation as it relates to, and intersects with, the realm of municipal finance. The thesis builds a case that municipal Heritage Property Tax Relief Programs (HPTRP's) in Ontario, as they currently exist, do not work as they were designed. HPTRP's are aimed at incentivizing heritage designation by offering a financial benefit to property owners, yet in their current configuration, result in additional costs that reduce their effectiveness. The ideal solution would be for the Province to review and redesign the program; however, this is unlikely. A practical solution, which is proposed in this paper, is for municipalities to create a Community Improvement Program (CIP) tool that off-sets some of the unforeseen costs associated with HPTRP's. The two programs have a history of working synergistically at the local level - and together can accomplish what HPTRP's were intended to achieve unilaterally.
\end{abstract}

Key words:

heritage conservation; heritage property tax relief programs; community improvement plans; heritage designation; Ontario 


\section{Acknowledgments}

I would like to thank my supervisor, Mitch Kosny, for being so amicable and supportive throughout the process of writing this MRP. Advice given by Michael Sawchuck - my second reader - has been a great help in both formulating and refining my topic. I am particularly grateful for the assistance given by public sector staff over the course of many months including: Andrew Jeanes, Paul King, Thomas Wicks, Michelle Drake, Stephen Ashton, Daniel Rende, Michael Vidoni and Eric Hanson. Finally, I wish to thank my parents for their support and encouragement throughout my time at graduate school. 


\section{$\underline{\text { Table of Contents }}$}

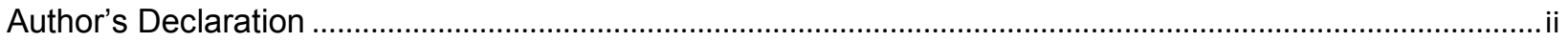

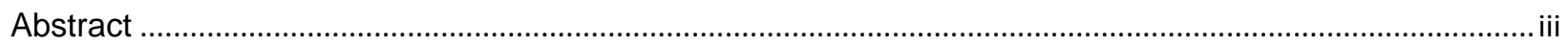

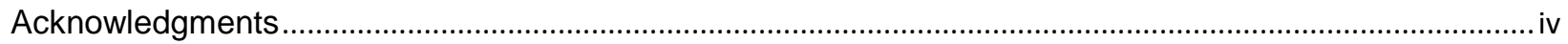

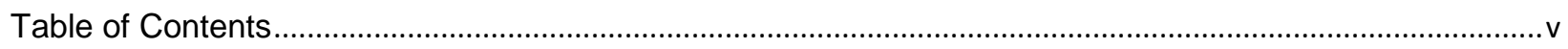

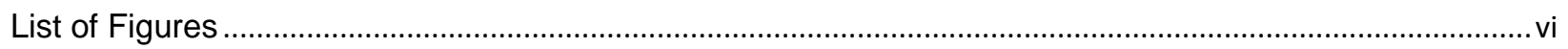

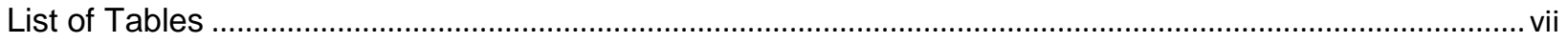

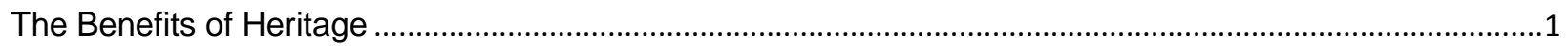

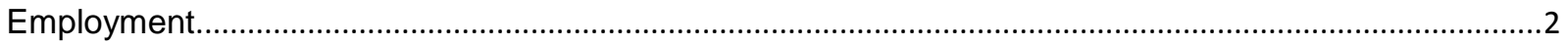

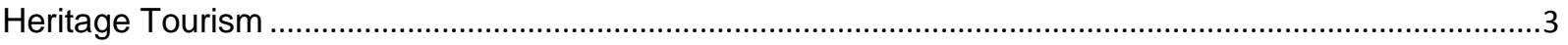

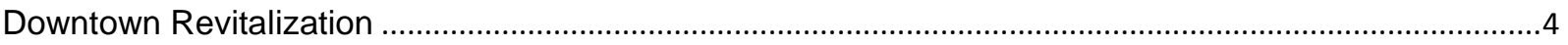

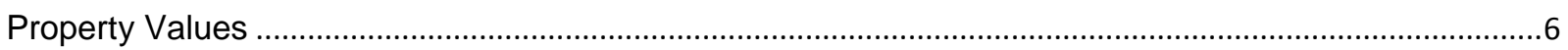

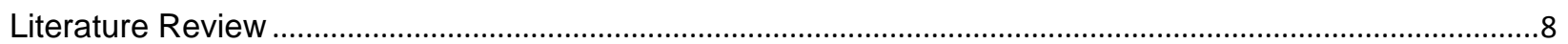

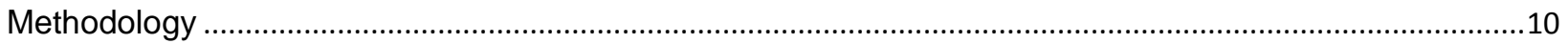

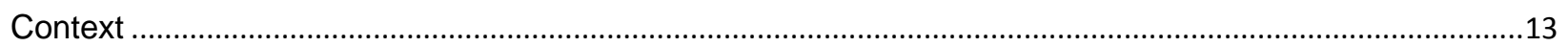

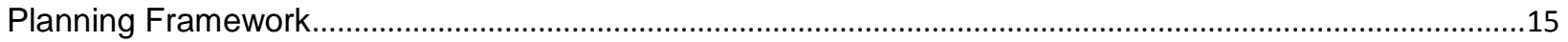

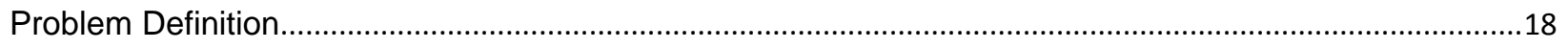

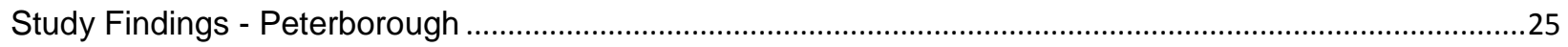

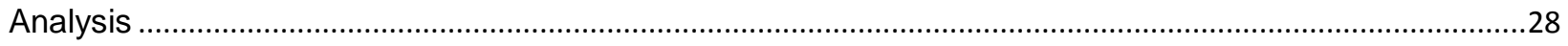

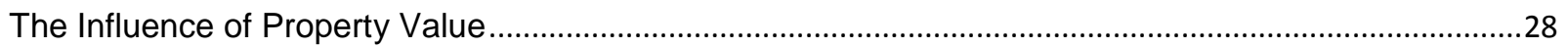

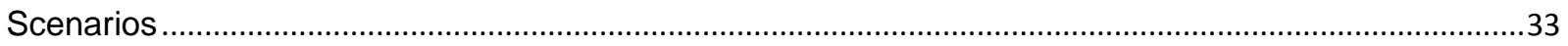

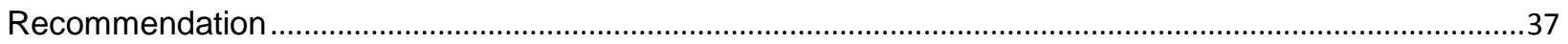

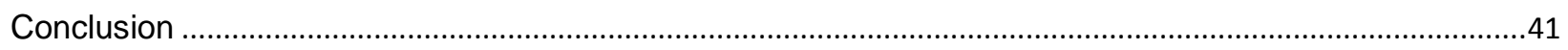

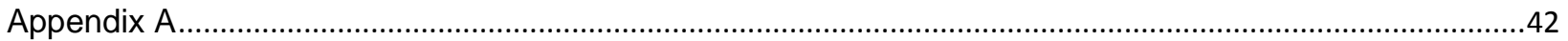

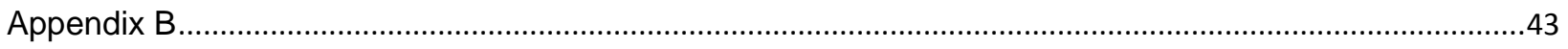

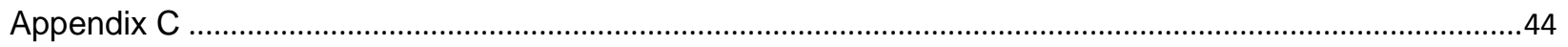

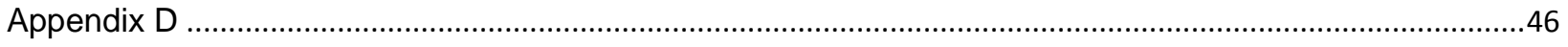

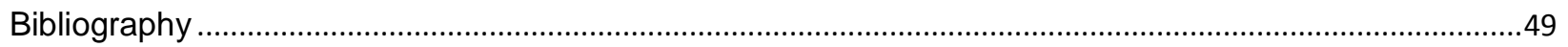




\section{List of Figures}

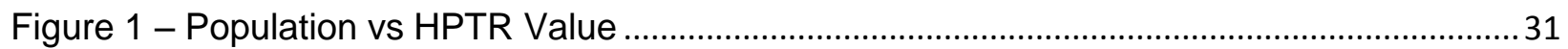




\section{List of Tables}

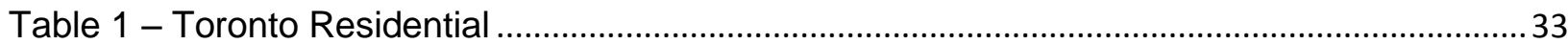

Table 2 - Penetanguishene Residential ........................................................................................ 34

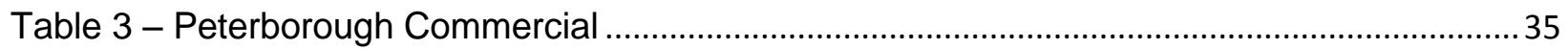

Table 4 - Toronto Residential Condensed...................................................................................... 38

Table 5 - Penetanguishene Residential Condensed ……………………………….................... 38

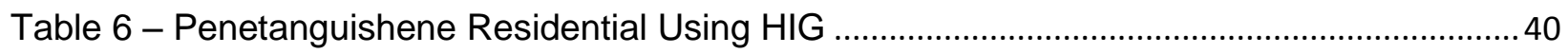




\section{The Benefits of Heritage}

Well maintained heritage properties enrich local quality of life and provide communities with a unique character and a distinctive sense of place. Restoring and conserving heritage properties has served as a catalyst for revitalizing historic downtowns and drawing residents, businesses and tourists to communities (City of Peterborough, 2011). In 1975, the Province enacted the Ontario Heritage Act (OHA), which provided municipalities and the Provincial government powers to preserve the heritage of Ontario. Heritage designation under the $\mathrm{OHA}$ has become an essential tool in the effort to preserve and protect historic neighbourhood districts and individual properties throughout the Province. The designation process strikes a balance between protecting individual property rights and preserving heritage resources in the interest of the public. In addition, there are many cultural, aesthetic, educational and economic benefits to rehabilitating and protecting significant heritage resources.

In municipalities across Ontario, historic properties have become valuable economic resources. They positively impact local economies through an array of different economic motivators, such as:

$\checkmark$ Job creation

$\checkmark$ Increased property values

$\checkmark$ Revitalization of neighborhoods, downtowns and/or commercial districts

$\checkmark$ Promotion of adaptive reuse resulting in increased tax revenue from vacant or under-utilized properties

$\checkmark$ Heritage tourism 
Additionally, from a municipal perspective, a strong preservation ethos contributes to:

$\checkmark$ Improved competitiveness of revitalized downtowns

$\checkmark$ Curbing urban sprawl and its associated new infrastructure costs

$\checkmark$ Diverting waste from demolished buildings

$\checkmark$ Enhanced community and civic pride

Rehabilitating a historic building generates both direct and indirect economic benefits (lbid.). Direct impacts are expenditures directly related to a project, such as design, labour, materials and technology (Ibid.). These direct costs can be higher than in new construction due to the specialized skill-sets of workers and unique materials used. Indirect impacts are expenditures that are associated with the production of valueadded supplies and services specific to the preservation industry like the provision of salvaged architectural features (lbid.).

\section{Employment}

Jobs related to heritage rehabilitation typically have a greater impact on the community than new construction work (Ibid.). Skills relevant to preservation work are more specialized and command higher wages. Also, preservation work typically relies more heavily on local craftspeople with knowledge of local traditions, materials and building techniques. Unlike heritage preservation work, modern construction techniques are premised on minimizing site labour by using pre-assembled and modular components that are manufactured and shipped from off-site (Ibid.). When a higher proportion of labour is locally sourced, more money remains in the local economy. A 2002 study by the Michigan Historic Preservation Network found that in new 
construction about $50 \%$ of cost is labour and $50 \%$ materials (Clarion Associates, 2002). The ratio for rehabilitation projects is typically $70 \%$ labour and $30 \%$ materials (Ibid.). The 2000 Downtown St. John's Strategy for Economic Development and Heritage Preservation report cites a 1986 study by the CMHC (Canadian Mortgage and Housing Corporation) which states that, "employment directly related to renovation projects generated an investment that was over twice the direct employment rate provided by an identical investment in new construction" (Canning \& Pitt Associates, Inc. \& Sheppard Case Architects Inc., 2000). The overall total employment - including indirect employment such as suppliers - was still considerably higher in building rehabilitations compared to new construction. Heritage property improvements also have a catalytic effect on investment in the surrounding area (City of Peterborough, 2011). Highly visible and centrally located projects (e.g. cornerstone or downtown commercial buildings) encourage surrounding building owners and investors to consider similar improvement projects (lbid.).

\section{Heritage Tourism}

According to Statistics Canada, in 1999 Canadians spent roughly three billion dollars in the heritage/cultural tourism sector (Ibid.). On their website, Heritage Canada discusses the four pillars of cultural tourism in the country: a) authenticity; b) historic architecture; c) family history; and d) learning and enrichment (Heritage Canada, 2014). The first two are particularly applicable in the municipal context. Being able to preserve a building's original façade, and its interior where feasible, contributes a great deal to its overall historic value. The latter two pillars are part of creating a complete experience 
for a tourist - being able to pair a tangible piece of history with 'its story'. Therefore, the benefits of a strong municipal relationship between tourism development and heritage preservation are significant. Heritage tourism is also a more economically potent sector of the tourism industry than others. In their report about tourism in Texas, Rutgers University found that more than $11 \%$ of all travelers in the state were heritage tourists (City of Peterborough, 2011). Furthermore, the report offered several other significant findings: cultural heritage tourists spent more money per day than non-heritage travelers; a higher percentage of cultural heritage travelers stayed in hotel accommodations than in private homes or with relatives; and, heritage travelers stayed in a particular location longer than tourists visiting for other reasons (Ibid.).

\section{Downtown Revitalization}

Communities across North America are taking advantage of their distinctive heritage assets to trigger revitalization and renewal of their historic business cores. Rehabilitating heritage buildings in a downtown core area produces a range of economic benefits for a municipality, such as:

$\checkmark$ Serving as an anchor and encouraging the migration of people and businesses to relocate, thereby creating newly viable residential and commercial space

$\checkmark$ Increasing property values

$\checkmark$ Returning underutilized or vacant buildings to municipal tax rolls

$\checkmark$ Increasing tourism

Core renewal and revitalization is beneficial to all sectors. Municipal governments gain from an increase in their property tax base and rates. Property owners benefit through 
increased occupancy rates and rental values. Vendors benefit from attractive and trendy locations. Finally, residents benefit from increased access to goods and services and greater local employment opportunities.

There are numerous impressive and award-winning examples of heritage conservation efforts leading to the revitalization of an urban core in Ontario, such as in Niagara-on-the-Lake, Peterborough and Port Hope. For instance, in a report published in 2003 by the University of Waterloo, the author discussed the economic downturn experienced in Port Hope's downtown, and how it later became the recipient of TVOntario's “The Best Preserved Main Street" award (Goddard-Bowman, 2003). Port Hope's downtown revitalization was a result of the restoration of heritage buildings in the core, which eventually led to:

$\checkmark$ The downtown becoming a magnet for antique stores and unique speciality shops

$\checkmark$ The tourism industry becoming one of the fastest growing sectors in the municipality, with the main downtown street serving as the key destination

$\checkmark$ The virtual extinction of vacant storefronts

$\checkmark$ A storefront being restored into a Performing Arts Centre, and expected to produce $\$ 3$ million in spin-off revenue and many new local jobs (Ibid.).

A different study, done by economist Dr. Chuck Chaprapani with the Centre for Study of Commercial Activity at Ryerson University, has produced research examining the impact of heritage preservation initiatives on the downtown core of Peterborough (Chaprapani \& Hernandez, 2010). The study found very strong support for heritage preservation among business owners and managers in the downtown core (Ibid.). In 
fact, $97 \%$ believed that heritage preservation was important, and $84 \%$ specifically said that they believe heritage preservation was important to the business environment of a community (lbid.).

The importance of heritage preservation to healthy and vibrant urban cores is demonstrated by the fact that two of Canada's largest urban centres, Toronto and Vancouver, both use density bonusing benefits to fund preservation efforts (Moore, 2013). For instance, Toronto's Implementation Guidelines for Section 37 of the Planning Act says benefits may be used to protect, restore or commemorate on-site heritage resources or off-site heritage resources in the local area (City of Toronto, 2007). Leveraging the value created by new development to help preserve historic resources is commendable, as the two are typically seen as being mutually exclusive. According to Aaron Moore, Toronto directs approximately 5\% of its Section 37 cash contributions towards heritage preservation, whereas Vancouver averages 18\% (Moore, 2013). In both cases this amounts to millions of dollars a year invested in heritage preservation.

\section{Property Values}

Understanding the relationship between heritage designation and property values is crucial to understanding the intent of HPTRP's. From a municipal perspective, it is intended that these programs cause an increase in property values, which in turn creates an increase in tax revenue, thereby helping offset the costs of administering the

program. The study by Dr. Chaprapani finds that this intended dynamic has been borne out in Peterborough. 
Changes in property values are also an indicator of changes in the desirability and liveability of a community. Rising property values in an area suggest that it is an attractive location, and people and/or businesses want to locate there. Several other studies exist that examine the correlation between heritage designation and property values in both Canada and the United States. The most well-known Canadian study was done by Robert Shipley, a professor at the University of Waterloo. He found that, "across the province the majority of individually designated properties, approximately $59 \%$, performed better than average in their value history trend when compared to the average property value trend in their communities. Another $15 \%$ performed in a way that was judged to be comparable to the average performance" (Shipley, 2000). A 2003 report by the New York City Independent Budget Office found that, “...for the entire 1975 through 2002 period properties in historic districts increased in price at a slightly greater rate than properties not in districts" (New York City Independent Budget Office, 2003). Rutgers University carried out a study examining the effects of designation on property values in nine American cities. The study concluded that, "Seven of these showed significantly higher property values within designated historic districts when compared with similar but non-designated areas. In some cases, there was as much as a 20\% difference between a designated and a non-designated area" (Rutgers University, 1999). As such, there is substantial evidence of a positive correlation between heritage designation and increased property values. 


\section{Literature Review}

Despite planning's profound impact on the physical world in which we live, it receives little attention in academia compared to other social science heavyweights like psychology or political science; and a small piece within the much larger planning umbrella is heritage conservation. The body of academic work dealing with heritage is slight, and it has almost exclusively focused on the link between heritage designation/preservation and economics. Essentially, it has sought to quantify the economic impacts of heritage conservation efforts (Asabere et al., 1989; Asabere \& Huffman, 1994a, 1994b; Ashworth, 2002; Benson and Klein, 1998; Coulson \& Leichenko, 2001, 2004; Kovacs et al., 2008; Leichenko et al., 2001; Lennox \& Revels, 2002; Listokin, 1985; Lockard \& Hinds, 1983; Rypkema, 1994; Schaeffer \& Millerick, 1991; Shipley, 2000, 2007, 2008). Thusly, the academic literature has provided evidence to show that heritage designation/preservation is an economically sound decision; however, has not looked at specific heritage programs. This report is specifically aimed at assessing and evaluating the effectiveness of municipal HPTRP's in the Province of Ontario. There is no existing academic work on this subject matter, which means there is no point of reference to compare and contrast findings. This report may serve as a baseline point of reference if further research and evaluation is done in this area.

Despite there being 40 municipalities that have passed HPTRP by-laws - some since 2003 - only one municipality has published a staff review of their program. The Council of the City of Peterborough directed staff to conduct a five-year review to 
determine whether their HPTRP had been achieving its intended goals. The Ontario Ministry of Tourism and Culture has rightly noted that, "the City of Peterborough is at the forefront of Municipal Cultural Planning" (OMTC, 2006). Beyond the staff report in Peterborough, there were no other useful municipal documents that spoke to the impacts of local HPTRP's. This is unfortunate as HPTRP's can be structured quite differently from municipality to municipality, and therefore, the impacts of these programs are likely to reflect this variability. In any case, the research presented in this paper can serve as a jumping off point for other researchers and government officials/representatives. 


\section{Methodology}

The idea for this report arose from conversations with other heritage professionals while working in the heritage field, and later through occasional correspondence. No formal interviews were conducted, and therefore, ethics approval was not required.

The core data set comes from quantitative data that is available online through a service provided by the Ministry of Municipal Affairs and Housing (MMAH). Since 1977, the Ministry has collected financial and statistical information from municipalities using a standard document called the Financial Information Return (FIR). Section 294(1) of the Municipal Act, 2001 requires each municipality to file an annual report on its financial affairs, accounts and transactions - which takes the form of the FIR. Of the 40 municipalities that have passed by-laws establishing an HPTRP, only 24 of those have provided tax relief under the program. For those municipalities the annual amount of tax relief provided each year is found on Schedule 72 under the section 'Tax Adjustments Applied to Taxation'. Line item 2399 - Reduction for Heritage Property (Mun. Act 365.2) - provides a full breakdown of the tax adjustments and the total tax relief in the far right column. The total tax relief value as the HPTR amount in a given year, for a given municipality, was entered into an excel spreadsheet - Appendix B. An example FIR sheet for Peterborough from 2011 is provided in Appendix A. It is noteworthy that, in certain years, the annual tax relief reported in the FIR for Peterborough did not match the values presented by municipal staff in their report reviewing the effectiveness of their program. The differences were not significant; 
however, it does serve as a reminder that there is likely a degree of error in both data sets. Where discrepancies existed, staff reports were used instead of FIR information. This decision reflects the belief that staff who administer the program would have more accurate data than municipal finance personnel.

2011 population figures from Statistics Canada for each of the 40 municipalities with an HPTRP were collected. The information used was found under the section 'Population and dwelling counts, for Canada and census subdivisions (municipalities), 2011 and 2006 censuses' in the file '98-310-XWE2011002-301.CSV'. The municipalities were sorted according to population size and plotted against total HPTR over the years 2002-2012. The resulting scatter plot depicts the relationship between population size and total tax relief provided under the program, since its inception, by each municipality. However, when the data is plotted on a linear scale it is strongly affected by outliers (i.e. Peterborough and Toronto), as well as the numerous 0 values on the $y$ axis. Plotting the data on a log-log scale minimizes the effects of outliers and does not display the 0 values on the chart, making the trend of increasing HPTR value with increasing total population more apparent. Also, due to the large range of values on both the $x$ and $y$ axis, a log-log scale is able to present the relationship between the variables more effectively than a linear scale.

To illustrate the relationship between the variables another way, the 40 municipalities were split into two halves, based on population. The HPTR totals for the top and bottom 20 were summed to draw attention to the large difference in total HPTR values. To ensure a fair comparison, the eligible years a municipality could participate were calculated - i.e. if they passed their HPTRP enabling by-law in 2005 they would be 
eligible to participate for 7 years (2006-2012). This contextualized the comparison. It would not be informative if the top 20 municipalities had significantly higher total HPTR values if, on average, they passed their by-laws earlier than the 20 less populous municipalities. The difference was extremely small and therefore the comparison was valid - the 20 most populous had a total of 121 eligible years compared to 115 for the bottom 20. The different charts based on this data are included in Appendix C. 


\section{Context}

In December of 2001, section 365.2 of the Municipal Act, R.S.O. 2001, c.25, was revised allowing a municipality to establish a by-law to create a Heritage Property Tax Relief Program. This tool, created by the Province, was devised to incentivize heritage designation, and is often used in conjunction with Community Improvement Plans (Province of Ontario, 2005). The primary aim of the program is to encourage good stewardship, maintenance and conservation of locally designated heritage properties. A municipality that has established a local HPTRP can begin to provide tax relief ranging between 10 and 40 percent of annual payments - to owners of protected heritage properties, subject to agreement to protect the heritage features of the property (Ibid.). This condition is important to recognize, as it has clear implications on the effectiveness of the program. The Province shares in the cost of this program by funding the education portion of the property tax relief (Ibid.). Municipalities that establish a HPTRP contribute to it by refunding a portion of the property tax they collect (Ibid.). Where applicable, upper-tier governments can also participate by forgiving a percentage of the portion of municipal property tax they collect; although according to my research, this has yet to occur.

As mentioned, in order to be eligible for enrollment in a HPTRP property owners must agree to protect the heritage features of their property. The general intent of a HPTRP is to grant a tax relief on the condition that the property owner will maintain the heritage features of their property. However, this eventually creates a problem, which is investigated in this report. The central focus for this paper, is how can municipal 
Community Improvement Plans (CIP's) be utilized to better incentivize heritage designation using the Ontario Heritage Act (OHA)? Specifically, how can they offset the costs faced by property owners enrolled in HPTRP's? 


\section{Planning Framework}

A brief description of the planning framework that underpins the aforementioned tools and programs is necessary to properly understand the issue at hand. The two key elements covered are the legislative underpinnings of heritage conservation in Ontario, and the legislative framework surrounding CIP's in the Province.

All aspects of heritage conservation in Ontario are guided by the Ontario Heritage Act $(\mathrm{OHA})$, which came into force in 1975. Its purpose is to give municipalities and the provincial government powers to preserve the heritage of Ontario. The primary focus of the Act is the protection of heritage buildings and archaeological sites. The legislation also mandates the Ontario Heritage Trust - a Crown agency - and the Conservation Review Board, a tribunal that hears objections to municipal and provincial decisions under the Act. In 2005, the Government of Ontario passed amendments to the Ontario Heritage Act to strengthen and improve heritage protection in Ontario.

Despite public perception, the age of a structure is not the only criteria in determining whether it is of heritage significance. Historical and cultural preservation is the value a property (or properties) holds for the local community and the municipality as a whole. The Provincial government created a resource known as the Ontario Heritage Tool Kit which consists of five parts and covers all aspects of heritage conservation in Ontario. On the topic of heritage properties it states that municipalities have a key role to play in conserving places that have cultural heritage value and they do so through the designation of properties under the Ontario Heritage Act. Heritage designation recognizes the importance of a property to the local community, protects 
the property's cultural heritage value, encourages good stewardship and conservation and promotes knowledge and understanding of the property. Property designation is not limited to buildings or structures, but can also include groups of buildings, cemeteries, natural features, cultural landscapes or landscape features, ruins, archaeological and marine archaeological sites, or areas of archaeological potential. Lastly, designation ensures a heritage property is appropriately managed and that changes are in keeping with the property's heritage value.

When a municipality deems a group of buildings to be historically significant and worthy of preservation it can protect them with what is known as a heritage conservation district (HCD). Designation of a heritage conservation district is a tool that a municipality can use to enable its council to manage and guide future change in the district. Each district has its own plan that outlines its policies and guidelines for conservation, as well as how to protect and enhance the area's special character. There is no pre-requisite size for the establishment of a district; sizes can vary from as small as a cluster of buildings to as large as the entire municipality. Districts can be comprised of urban or rural environments, or a combination of both. Further, they may include residential, commercial and industrial areas, rural landscapes or entire villages or hamlets with features or land patterns that contribute to a cohesive sense of time or place.

The Province gave municipalities the power to establish HPTRP's under section 365.2 of the Municipal Act, 2001. This section has eighteen sub-sections that stipulate all of the details relating to municipal HPTRP's, such as what constitutes an eligible heritage property, the allowable range of the tax reduction and by-law requirements, etc. 
Community improvement plans are intended to address municipal or regional planning objectives in a certain defined area through municipally-driven and/or incentive-based programs (Province of Ontario, 2008). The municipal practice of providing financial or other similar assistance to businesses is often called bonusing. Under the rule against bonusing, with certain exceptions, municipalities are prohibited from directly or indirectly assisting any manufacturing business or other industrial or commercial enterprises through the granting of certain financial incentives (Ibid.). However, there are exceptions to the rule against bonusing (Ibid.). For example, to carry out a community improvement plan, municipalities, despite the general prohibition against bonusing, can devise tools to assist businesses, properties being redeveloped, heritage buildings, etc. (Ibid.). Section 28 of the Planning Act, and sections 106 and 365.1 of the Municipal Act, 2001 provide the primary legislative framework for community improvement planning in the Province of Ontario (Ibid.). 


\section{Problem Definition}

Currently, municipalities in the Province of Ontario can create CIP's to address planning objectives within a defined area through various financial programs/schemes. Due to the discretionary nature of CIP's, some municipalities offer more tools than others to support, among other things, heritage properties. For example, some municipalities have not created any CIP's whatsoever, while others have created a whole range of CIP's. The rationale for having numerous different programs is to allow a municipality to target assistance to different types of projects, such as brownfield redevelopment; or to different scales/locales, e.g. downtowns, business improvement areas or specific communities. Hamilton is an example of a municipality that created an entire CIP exclusively concerning heritage properties. However, few municipalities have heritage-specific CIP's; instead, most opt to include a program/tool that can apply to heritage properties within a general CIP. The most common municipal CIP tool utilized by heritage property owners is the building, façade, and signage improvement loan program; however, this generally only applies to commercial buildings located in a downtown, and thus the vast majority of designated properties are ineligible. Other tools, such as a rehabilitation/redevelopment grant aimed at heritage buildings, often go unused based on how they are structured. This is because the building/façade improvement loan tends to be the most lucrative program for heritage buildings.

Despite the programs that currently exist to assist heritage property owners, municipal CIP's could better support heritage designation by combating the current issues surrounding municipal HPTRP's. 
As with any governmental policy or program, it is impossible to foresee all of the possible outcomes. With several layers of government and overlapping objectives, it is inevitable that a new policy/program will create unintended consequences. In the case of HPTRP's in the Province, there are two main issues that have been created. The first issue lies in the fact that homeowners frequently re-invest the tax relief savings accrued through a HPTRP back into their property, thereby increasing its value. Eventually homeowner's have re-invested in their property to a point where even with the municipal and education portions of their property tax forgiven, their home is assessed at a worth that has them paying more in property taxes than before they started receiving the municipal tax relief. This scenario can create a vicious cycle. To better illustrate this point, an actual case from Peterborough is provided:

The owner has invested over $\$ 100,000$ to convert a heritage building to offices and make several existing apartments on upper floors code compliant. The work included some restoration of heritage attributes protected by heritage designation at a cost of about $\$ 8,500$. The total rehabilitation work resulted in a $\$ 142,000$ increase in the MPAC assessment. This reassessment resulted in an increase of $\$ 6,653.14$ in taxes annually. Since the property has been in the program the owner has paid approximately $\$ 47,000$ in taxes while receiving $\$ 10,780$ in heritage tax relief. The owner's conclusion is that the HPTRP is a token and not a meaningful contribution to restoration projects (City of Peterborough, 2011).

Some may argue that all properties rise in value both over time, and as they are improved, which is true. However, the intent of an HPTRP is ultimately to incentivize heritage designation and conservation, so offering a program that is economically beneficial in the short-term, but in the long-term more expensive for a property owner, subverts its purpose. Owners of historically significant properties should receive an economic benefit irrespective of how diligently they maintain and/or better the heritage 
elements of their property. Others may argue that the tax increases are driven by capital improvements that generate either improved revenue streams for commercial properties or higher sale prices for residential properties, and therefore a rise in property value is appropriate. This point, however, does not look at all of the realities of the situation. In the case of residential property owners, they can only benefit from a higher sale price when they actually sell their house, which may not happen for years or even decades. In that time, the amount of additional money they will pay in property taxes as a result of their property value rising will be significant. Even if the homeowner(s) are able to pay this increase without trouble, it could negatively impact their willingness to further improve the heritage attributes of their property in the future. In addition, heritage conservation carries a (largely misplaced) stigma with residential and commercial property owners alike, that designation brings with it nothing but red tape and costly financial obligations. As mentioned, the chief aim of HPTRP's is to combat this perception, not further entrench it.

The second consequence of HPTRP's stems from their eligibility requirements. As outlined, the empowering legislation for HPTRP's is the Municipal Act, 2001. Within the section of the Act that permits municipalities to create HPTRP's is a subsection which defines the eligibility requirements of an "eligible heritage property". These are as follows:

(a) that is designated under Part IV of the Ontario Heritage Act or is part of a heritage conservation district under Part $\mathrm{V}$ of the Ontario Heritage Act,

(b) that is subject to,

(i) an easement agreement with the local municipality in which it is located, under section 37 of the Ontario Heritage Act, 
(ii) an easement agreement with the Ontario Heritage Foundation, under section 22 of the Ontario Heritage Act, or

(iii) an agreement with the local municipality in which it is located respecting the preservation and maintenance of the property, and

(c) that complies with any additional eligibility criteria set out in the by-law passed under this section by the local municipality in which it is located. 2002, c. 17, Sched. A, s. 69.

This means that a property must be designated, but more importantly, must also be protected by an easement agreement with either the municipality or the Ontario Heritage Trust (the Ontario Heritage Foundation was changed to the Ontario Heritage Trust in 2005) to meet the eligibility requirements for enrollment in a HPTRP. The rationale for requiring an easement, in addition to being designated, is due to the fact that easements are more comprehensive in their ability to protect a property than designation. For instance, "there are no provisions under the Ontario Heritage Act to require an owner of a designated property to maintain the building or its heritage features in good condition, ensure the building against perils or to rebuild the building in the event of damage. Heritage easements address these shortcomings. Easements also provide much stronger protection against demolition" (City of Markham, 2013).

However, many of the features of an easement that make it more comprehensive, also make it more expensive - both in the short- and long-term - for property owners. In the short-term, there is the cost of the easement itself. Costs vary based on the property size and type, among other things. A professional is required to assess the property and create a baseline document, which is essentially a thorough snap-shot of the building and the condition of its heritage elements at the time of the easement. Precise figures for the total cost of preparing an easement could not be 
found; however, would not be insignificant to a property owner. In addition, the strict requirements an easement places on a property owner to diligently ensure the building, and all of its heritage elements, are in a sound state of repair equates to higher-thannormal carrying costs. It is widely recognized that heritage properties require more intensive care, custom work and restoration at a higher cost than one would encounter with newer buildings (Ibid.). Mandating a certain standard of care also requires a property owner to reinvest some of the savings accrued through an HPTRP back into their property. This prevents a property owner from using the tax savings on items other than maintaining the heritage building. Finally, and perhaps most importantly, an easement requires a property owner to insure the property to certain standards. Insurance companies are understandably not sensitive to the importance of preserving heritage buildings, and see them simply as being high risk. Also, easements do require certain heritage elements to be replaced in like kind and quality in the event of damage. The tension between insurance companies and heritage designation is well documented. Heritage property owners have seen their policies cancelled or their rates rise dramatically after designation. One homeowner in Wentworth, N.S., had to have the municipal heritage designation removed before she could renew her home insurance (Ascroft, 2004). Don Tonsaker, HSBC Vice-President, found his insurance company no longer wanted to provide coverage of his heritage home after it was designated (Ibid.). Allstate Insurance has commented regarding heritage buildings, "We as a rule will not underwrite, so they receive no coverage" (Ibid.). Stacy Elliott, a broker from Ottawa, summarizes the chief concern insurers have with designated buildings, "Older homes have materials that were used 80 years ago but which are not available 
today. This requires the companies to custom make and custom order the materials, driving up the replacement cost of the building and the premium charged" (Ibid.). The aforementioned cases deal with buildings that have just been designated, and do not have easements. Therefore, for properties enrolled in a HPTRP that have designation and an easement, securing home insurance at a reasonable rate will prove even more problematic.

In sum, HPTRP's are marketed as offering a property owner a financial incentive in exchange for having their property historically designated. In reality, however, the eligibility requirements of the program, and escalating property taxes as a result of the standards of care stipulated by an easement, results in a set of financial disincentives that could very easily exceed any tax savings under the program. Certain circumstances impact the degree to which the financial costs outweigh the benefits, and are discussed in the analysis section of the paper. In any case, if HPTRP's are to truly offer property owners a tangible and long-lasting financial incentive, they must increase the monetary inducements offered as part of enrollment in the program. CIP's are a logical place to look for a solution to this monetary issue as they are well-documented for providing financial benefits to property owners. Also, as mentioned earlier, HPTRP's can be used in conjunction with CIP's, meaning there is a precedent of the two tools working synergistically. In addition, based on personal experience working for several different municipal governments, not all of the funding allocated to CIP's is used year-toyear. As such, a viable solution to the vicious cyclical problem caused by HPTRP's may be based on a new CIP tool on a case-by-case basis. It is unlikely that the overall cost 
to each municipality will be extensive, and therefore by using a CIP tool, the expenses could be taken from the surplus funding allocated to municipal CIP's. 


\section{Study Findings - Peterborough}

Of the forty municipalities in the Province with an HPTRP, the City of Peterborough is the only one that produced a public report reviewing the effects of the program. Planners at the City were instructed to complete a five-year review to assess whether the program had achieved its intended goals. The key metric discussed in the assessment was the program's impact on property values between the years 2003 to 2009. The participating properties were divided into three categories: non-designated, designated but not included in the HPTRP, and designated and in the HPTRP (City of Peterborough, 2011). The results were surprising and show the effectiveness of the program in increasing property values at a substantial rate. Although it is impossible to generalize the results from Peterborough to all other municipalities, it is likely that market mechanics and a central assessment body (MPAC) would result in similar findings. In fact, it is likely that the effects would be even more pronounced in larger urban centers (such as Toronto) where land values are higher.

The average annual rate of increase in the assessed value of all non-designated properties, commercial and residential, for the years 2003 to 2009 was $7.12 \%$ (Ibid.). This was higher than the average increase for designated properties not in the tax relief program, which was $5.61 \%$ over the same period (lbid.). This suggests that when no tax incentive was offered, heritage designation slightly limited assessment growth in Peterborough. A possible explanation for this is the fact that Ontario municipalities use market rate assessments generated by MPAC through a complicated evaluation of factors (Ibid.). Five factors, including the size of the lot, the size of the building and the 
age of the building make up $85 \%$ of the property value (Ibid.). Therefore, MPAC devalues a building the older it is. By definition, heritage value increases as a building ages - and by extension, its likelihood to be designated (Ibid.). Other studies, including several by Waterloo professor Robert Shipley, have shown property values for heritage buildings have increased at either the same or a slightly higher rate than nondesignated properties, but he only looked at properties in Heritage Conservation Districts (and not individually designated properties as is the case in Peterborough) (Shipley, 2000; 2007; 2008). However, the numbers are substantially different for properties in the HPTRP. These buildings saw their assessed values rise by an average of $28.09 \%$ annually (City of Peterborough, 2011). This is a staggering four times higher than non-designated properties and approximately five times higher than designated properties not in the HPTRP (Ibid.).

The impressively large increases in property value for designated buildings in the HPTRP are largely attributable to formerly vacant or completely depreciated commercial buildings - in the downtown - that underwent major rehabilitation (Ibid.). In fact, several commercial properties in Peterborough had average annual increases in assessed value of over $100 \%$ after they entered the HPTRP (Ibid.). Clearly, based on this, there is a trend for designated commercial properties to undergo major rehabilitations with support from the tax relief program. Thusly, the program is acting as a strong incentive for revitalization; however, that same revitalization brings with it a substantial year-overyear increase in assessed value and property tax payments.

Figures provided in Appendix 2 of the staff report show that between 2003 and 2009 the City of Peterborough paid just shy of $\$ 530000$ to properties participating in the 
HPTRP (Ibid.). This figure does not account for the rebate the City receives from the Provincial government for the education portion of property tax (Ibid.). It is also important to remember that those tax savings led to substantial increases in assessment values, and consequently, greater municipal revenue - which offsets some of the program costs (Ibid.). In addition, numerous large commercial properties that were formerly vacant have been revitalized and thereby returned to municipal property tax rolls (Ibid.). Further benefits are more difficult to quantify. Repurposing designated commercial buildings and improving/renovating designated residential buildings all help to create a stronger sense of place, mixed use development, local economic activity and more attractive tourist locations. Based on this, the potential benefits of a thriving HPTRP are undeniable; however, so are the escalating costs to property owners. As such, fewer and fewer residential properties are able to take advantage of the benefits of the HPTRP. During conversation with a heritage planner in Toronto, it was learned that roughly half of the monies allocated to Toronto's HPTRP are being used by only two commercial properties. This draws attention to the reality that the tax relief provided by a HPTRP becomes increasingly lucrative for properties paying the most in property tax. 


\section{Analysis}

As mentioned, the crux of the issue with HPTRP's as they currently exist, is the inherent contradiction between offering property owners a financial incentive to designate their property, and creating requirements that essentially force the owner into paying extraneous costs to maintain their eligibility in the program. Also, the additional costs discussed in the previous section are not apparent to prospective property owners' considering enrollment in their local HPTRP. They would only begin to realize the costs once they paid for an easement and tried to secure property insurance. The higher carrying costs would not be realized until after enrollment. The likely reaction of any property owner to this scenario would be the same as the individual in Peterborough, who felt the program was merely a token effort at incentivizing heritage designation and restoration. The discrepancy between unforeseen costs versus tax relief under the program is dependent on certain factors, according to my analysis.

\section{The Influence of Property Value}

The single most important factor in determining whether it is financially beneficial for a property owner to enrol in a municipal HPTRP is property value. This is because a property with a high assessment value, determined by MPAC, will pay more in property taxes each year. The total tax relief provided under a HPTRP is determined by refunding a percentage (anywhere between 10-40\%) of the education and municipal portion of the property tax. Therefore, the more a property owner pays in property tax per annum, the more they will receive in tax relief. And the more a property owner receives in tax relief, the less the additional costs associated with HPTRP eligibility will 
impact their bottom line, since the costs are incurred irrespective of how much tax relief a property owner receives. Ultimately, this means that HPTRP's should be used most vigorously in markets where land values are the highest, or by land uses that are assessed at the greatest worth. However, does the data support this assertion?

The two municipalities that have provided the most tax relief as part of their HPTRP's are Toronto and Peterborough. Toronto provided a total tax relief of $\$ 4,446,012$ in the period $2008-2012$, and Peterborough has forgiven a total of $\$ 1,168,099$ between the years $2004-2012$. Toronto currently has average land values that are known for being remarkably high, by national and even international standards. Peterborough on the other hand does not, so why have they seen such impressive uptake in their HPTRP? When creating their HPTRP, Peterborough stipulated additional eligibility criteria in an effort to support strategic community development objectives. They constrained eligibility by creating a zone, whereby only properties that were within the zone, and met all the other criteria as set out in the Municipal Act, 2001, would be eligible. Essentially, the zone consisted of their downtown, as they were using their program to specifically target the rehabilitation of certain kinds of properties (e.g. commercial, office, multi-residential) and regenerate a specific area (e.g. their town centre). In other words, Peterborough sought to leverage their HPTRP to revitalize their historic downtown building stock, and return many vacant or under-utilized properties back to municipal tax rolls. The combination of downtown land values and commercial or multi-residential land uses meant that the assessment values for many of the properties enrolled in the Peterborough HPTRP were very high. As such, the amount they received in tax relief was substantial, and far outweighed the additional costs of 
eligibility. On the other hand, a residential heritage property in a rural municipality would have a much lower assessed value than an identical house with the same lot size located in Toronto. Having a lower assessed value would mean the owner of the rural heritage property would pay less in property taxes, and therefore receive less in tax relief. However, as both the short- and long-term additional costs of enrollment in an HPTRP are fixed, the proportion of costs to tax relief will be much higher for the rural property owner. This point is clarified later in the analysis section using three different scenarios - Tables 1-3. So to answer the question, yes, the data supports the assertion that land value is the single most important factor in determining how lucrative enrollment in a HPTRP will be for a property owner. To fully substantiate this observation, data from Appendix B was used to construct several scatter plots.

The following plot uses log-log scales for reasons stated in the methodology section. It shows the correlation - having an $\mathrm{R}$ squared value of 0.517 - between total population and total HPTR provided, per municipality, per year. Except for a few outliers - in this case Ajax and Oshawa, both municipalities with fairly large populations, but small HPTR totals - the causal relationship between the variables is evident. As population increases, so too does the total HPTR total. 


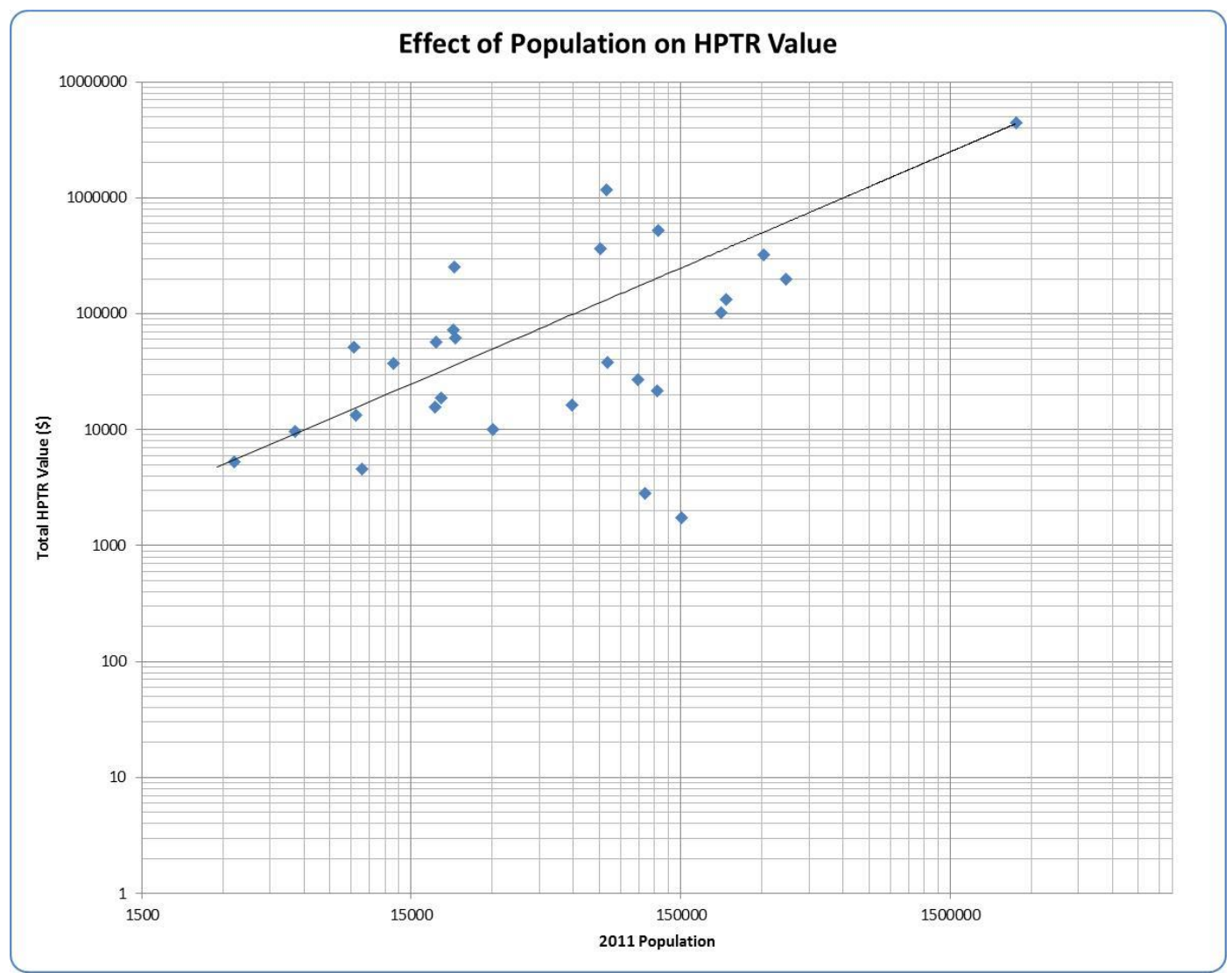

Figure 1 - Population vs HPTR Value

In the above chart, population size is used as a proxy for land value. I make the assumption that more populated areas have higher land values for several reasons. Firstly, high population areas are more urbanized, and urban land is generally worth more than rural land due to its development potential. Also, a denser concentration of people brings with it higher levels of monetary investment and economic activity. In addition, most of the value of land stems from its proximity to agglomerations of economic activity. So, concentrations of people result in increased economic activity, and proximity to economic activity is a principle factor in land valuation. Finally, a large population puts increased pressure on the demand side of development, thereby 
increasing the worth of the available supply. Based on this information, it is safe to assume a strong causal relationship between land values and population totals.

The relationship between land value and HPTR is problematic. It provides an advantage to particular property types and particular geographic locations. Properties used for non-residential purposes - e.g. commercial, office - will have the largest advantage because those uses are assessed higher by MPAC. Geographically, the farther a property is from a large urban centre - such as Toronto - the less valuable the land it sits on becomes. As such, the benefits accrued to a multi-storey commercial heritage building in downtown Toronto would be far greater than a residential heritage home in a rural municipality. The following scenarios - which are also included as Appendix D - highlight this dynamic. 


\section{Scenarios}

\begin{tabular}{|c|c|c|c|c|c|c|c|}
\hline \multicolumn{8}{|c|}{ Residential Home in Toronto } \\
\hline & Year 1 & & Year 2 & & Year 5 & & Year 10 \\
\hline Property Value ${ }^{1}$ & $\$ 553,193$ & & $593,576.09$ & & $733,289.66$ & & $042,975.66$ \\
\hline $\begin{array}{l}\text { MLS Home Price Index (HPI) } \\
\text { Composite Benchmark }^{2}\end{array}$ & $7.30 \%$ & & $7.30 \%$ & & $7.30 \%$ & & $7.30 \%$ \\
\hline Property Tax ${ }^{2}$ & $\$ 4,125.52$ & $\$$ & $4,426.68$ & $\$$ & $5,468.61$ & $\$$ & $7,778.15$ \\
\hline Education Portion & $\$ 1,173.41$ & $\$$ & $1,258.38$ & $\$$ & $1,554.57$ & $\$$ & $2,211.11$ \\
\hline City Portion & $\$ 2,954.35$ & $\$$ & $3,168.30$ & $\$$ & $3,914.04$ & $\$$ & $5,567.04$ \\
\hline HPTRP Application $\mathrm{Fee}^{3}$ & $\$ 100.00$ & & $\mathrm{~N} / \mathrm{A}$ & & $\mathrm{N} / \mathrm{A}$ & & $\mathrm{N} / \mathrm{A}$ \\
\hline HPTR (30\%) & $\$ 1,237.66$ & $\$$ & $1,328.00$ & $\$$ & $1,640.58$ & $\$$ & $2,333.45$ \\
\hline Estimated Easement Cost & $\$ 500.00$ & & $\mathrm{~N} / \mathrm{A}$ & & $\mathrm{N} / \mathrm{A}$ & & $\mathrm{N} / \mathrm{A}$ \\
\hline $\begin{array}{l}\text { Estimated Required Upkeep } \\
\text { Costs on Heritage Features, } \\
\text { Per Annum }{ }^{4}\end{array}$ & $\$ 850.00$ & $\$$ & 871.25 & $\$$ & 938.24 & $\$$ & $1,061.53$ \\
\hline $\begin{array}{l}\text { Estimated Increase in Insurance } \\
\text { Premium due to Easement, Per } \\
\text { Annum }^{4}\end{array}$ & $\$ 350.00$ & $\$$ & 358.75 & $\$$ & 395.99 & $\$$ & 448.03 \\
\hline $\begin{array}{l}\text { Yearly Net Value of Enrollment } \\
\text { in HPTRP }\end{array}$ & $-\$ \quad 562.34$ & $\$$ & 98.00 & $\$$ & 306.35 & $\$$ & 823.88 \\
\hline
\end{tabular}

\section{Table 1 - Toronto Residential}

This scenario provides a cost-benefit analysis for a hypothetical historic residential home in Toronto using both researched and estimated numbers. The first seven rows display researched values based on the average home price in Toronto as of February 2014. The following three rows - representing the costs associated with enrollment - provide figures that are educated approximations. Also, it is unlikely that the current average annual increase in residential property values will be $7.3 \%$ for the next ten years, however, this analysis gives a good estimation for illustration purposes. In year one, the property owner would have incurred more costs than tax relief received, due to the upfront costs of enrollment. Beyond year one, the property owner records a 
positive net value from enrollment, with that value increasing each subsequent year as costs increase at a slower rate than property value. This scenario shows the strength of a HPTRP in a strong real estate market. Contrast this with the next scenario, which provides the same cost-benefit analysis for a hypothetical historic residential home in Penetanguishene.

\begin{tabular}{|c|c|c|c|c|c|c|c|}
\hline \multicolumn{8}{|c|}{ Residential Home in Penetanguishene } \\
\hline & Year 1 & & Year 2 & & Year 5 & & Year 10 \\
\hline Property Value ${ }^{1}$ & $\$ 314,000$ & & $319,966.00$ & & $344,985.28$ & & $408,665.73$ \\
\hline $\begin{array}{l}\text { MLS Home Price Index (HPI) } \\
\text { Composite Benchmark }{ }^{1}\end{array}$ & $1.90 \%$ & & $1.90 \%$ & & $1.90 \%$ & & $1.90 \%$ \\
\hline Property Tax ${ }^{2}$ & $\$ 4,498.38$ & $\$$ & $4,583.85$ & $\$$ & $4,942.28$ & $\$$ & $5,854.57$ \\
\hline Education Portion & $\$ 666.31$ & $\$$ & 678.97 & $\$$ & 732.06 & $\$$ & 867.19 \\
\hline City Portion & $\$ 2,225.99$ & $\$$ & $2,268.29$ & $\$$ & $2,445.65$ & $\$$ & $2,897.09$ \\
\hline County Portion & $\$ 961.11$ & $\$$ & 979.37 & $\$$ & $1,055.95$ & $\$$ & $1,250.87$ \\
\hline OPP Portion & $\$ 645.60$ & $\$$ & 657.86 & $\$$ & 709.30 & $\$$ & 840.23 \\
\hline HPTRP Application $\mathrm{Fee}^{3}$ & $\$ 100.00$ & & $\mathrm{~N} / \mathrm{A}$ & & $\mathrm{N} / \mathrm{A}$ & & $\mathrm{N} / \mathrm{A}$ \\
\hline HPTR (40\%) & $\$ 1,156.92$ & $\$$ & $1,178.90$ & $\$$ & $1,271.08$ & $\$$ & $1,505.71$ \\
\hline Estimated Easement Cost & $\$ 500.00$ & & N/A & & $\mathrm{N} / \mathrm{A}$ & & N/A \\
\hline $\begin{array}{l}\text { Estimated Required Upkeep } \\
\text { Costs on Heritage Features, } \\
\text { Per Annum }{ }^{4}\end{array}$ & $\$ 850.00$ & $\$$ & 871.25 & $\$$ & 938.24 & $\$$ & $1,061.53$ \\
\hline $\begin{array}{l}\text { Estimated Increase in Insurance } \\
\text { Premium due to Easement, Per } \\
\text { Annum }^{4}\end{array}$ & $\$ 350.00$ & $\$$ & 358.75 & $\$$ & 395.99 & $\$$ & 448.03 \\
\hline $\begin{array}{l}\text { Yearly Net Value of Enrollment } \\
\text { in HPTRP }\end{array}$ & -\$ 643.08 & $-\$$ & 51.10 & $-\$$ & 63.15 & $-\$$ & 3.85 \\
\hline
\end{tabular}

Table 2 - Penetanguishene Residential

This second scenario shows that with lower property values, and smaller annual growth in property values, the yearly net value of enrollment is negative for the projected periods. This is despite Penetanguishene's HPTRP providing a $40 \%$ relief compared to Toronto's $30 \%$. The same figures were used for upkeep costs and 
insurance premium increases as in the Toronto scenario. These values may actually be slightly less in this example; however, the average property values would likely be lower as well, because the given numbers represent the average for the Barrie CMA - which includes Penetanguishene - but also more valuable markets like Barrie. Even if the costs are off by a small margin, the large difference in net value shows undeniably the impact a lower property value has on the viability of enrollment in a HPTRP. The final scenario examines a hypothetical commercial property in downtown Peterborough.

\begin{tabular}{|c|c|c|c|c|c|}
\hline \multicolumn{6}{|c|}{ Commercial Property in Peterborough } \\
\hline & Year 1 & Year 2 & Year 5 & & Year 10 \\
\hline Property Value ${ }^{1}$ & $\$ 578,000$ & $\$ 614,760.80$ & $\$ 786,718.72$ & & $1,370,327.71$ \\
\hline $\begin{array}{l}\text { Average Annual Growth for } \\
\text { Commercial Properties }{ }^{1}\end{array}$ & $6.36 \%$ & $6.36 \%$ & $6.36 \%$ & & $6.36 \%$ \\
\hline Property Tax ${ }^{2}$ & $\$ 14,493.08$ & $\$ 15,414.84$ & $\$ 19,726.60$ & $\$$ & $34,360.32$ \\
\hline Education Portion & $\$ 1,225.36$ & $\$ 1,303.29$ & $\$ 1,667.84$ & $\$$ & $2,905.09$ \\
\hline City Portion & $\$ 13,267.72$ & $\$ 14,111.55$ & $\$ 18,058.76$ & $\$$ & $31,455.23$ \\
\hline HPTRP Application Fee ${ }^{3}$ & $\$ \quad 100.00$ & $\mathrm{~N} / \mathrm{A}$ & $\mathrm{N} / \mathrm{A}$ & & $\mathrm{N} / \mathrm{A}$ \\
\hline HPTR (20\%) & $\$ 2,898.62$ & $\$ 6,165.94$ & $\$ 7,890.64$ & $\$$ & $13,744.13$ \\
\hline Estimated Easement Cost & $\$ 500.00$ & $\mathrm{~N} / \mathrm{A}$ & $\mathrm{N} / \mathrm{A}$ & & $\mathrm{N} / \mathrm{A}$ \\
\hline $\begin{array}{l}\text { Estimated Required Upkeep } \\
\text { Costs on Heritage Features, } \\
\text { Per Annum }{ }^{4}\end{array}$ & $\$ 1,500.00$ & $\$ 1,537.50$ & $\$ \quad 1,655.72$ & $\$$ & $1,873.29$ \\
\hline $\begin{array}{l}\text { Estimated Increase in Insurance } \\
\text { Premium due to Easement, Per } \\
\text { Annum }{ }^{4}\end{array}$ & $\$ 750.00$ & 768.75 & 848.56 & $\$$ & 960.06 \\
\hline $\begin{array}{l}\text { Yearly Net Value of Enrollment } \\
\text { in HPTRP }\end{array}$ & 48.62 & $\$ 3,859.69$ & $\$ \quad 5,386.37$ & $\$$ & $10,910.77$ \\
\hline
\end{tabular}

Table 3 - Peterborough Commercial

This third scenario uses figures based on an actual property in Peterborough and displays a cost-benefit analysis for a high value land use, located downtown, in an average real estate market. Upkeep costs and insurance premiums were both 
increased for this example to reflect the change to a multi-storey commercial building. Even with the higher costs and a lower annual growth rate compared to Toronto, the net values are significantly higher by virtue of the higher tax rate applied to commercial uses and higher overall property values. As a result, commercial property owners pay considerably more in property tax, meaning they receive a larger tax relief as a proportion of the extraneous costs of HPTRP eligibility. Consequently, it can be very lucrative for a commercial property owner, or a residential property owner with a high property value, to enroll in the program. On the other hand, for a residential property owner in a lower value market, enrolling in their local HPTRP does not make sense financially, as accrued costs outstrip gains. 


\section{Recommendation}

My recommendation to ameliorate this issue lies in the pairing of a HPTRP with a CIP. As previously mentioned, the most likely scenario would be to create a new CIP encompassing the same geographic area that the HPTRP covers. The CIP - referred to herein as the Heritage Incentivization Grant $(\mathrm{HIG})$ - will create a more uniform benefit for heritage property owners. It would temper the advantages of certain property uses and have an equalizing effect on the role of property values on the viability of HPTRP enrollment. As the three scenarios demonstrated, the most vital metric in determining the viability of HPTRP enrollment is the yearly net value. This figure weighs the financial tax relief benefit against the costs associated with eligibility. A negative value means enrollment in the program will result in a property owner incurring higher costs than benefits for a given year. A positive value demonstrates viability, and a value close to 0 indicates a property owner will break even, and therefore, that enrollment is unnecessary. In the Penetanguishene scenario, the property owner would either have to receive a larger HPTR or incur fewer costs. Subsidizing costs is untenable as they are inconsistent from year-to-year and would vary widely from property to property. As a result, providing a larger tax benefit is a far more predictable and fair solution. Revisiting the residential scenarios in both Toronto and Penetanguishene, we see that the property owner in the latter actually pays more in property tax each year due to higher municipal tax rates, yet receives a smaller HPTR. This is despite the fact that the HPTRP in Penetanguishene forgives $40 \%$, to Toronto's $30 \%$, of property tax. 


\begin{tabular}{|c|c|c|c|c|c|c|}
\hline \multicolumn{7}{|c|}{ Residential Home in Toronto } \\
\hline & Year 1 & Year 2 & & Year 5 & & Year 10 \\
\hline Property Value $^{1}$ & $\$ 553,193$ & $\$ 593,576.09$ & & $733,289.66$ & & $1,042,975.66$ \\
\hline $\begin{array}{l}\text { MLS Home Price Index (HPI) } \\
\text { Composite Benchmark }^{2}\end{array}$ & $7.30 \%$ & $7.30 \%$ & & $7.30 \%$ & & $7.30 \%$ \\
\hline Property Tax ${ }^{2}$ & $\$ 4,125.52$ & $\$ \quad 4,426.68$ & $\$$ & $5,468.61$ & $\$$ & $7,778.15$ \\
\hline Education Portion & $\$ 1,173.41$ & $\$ 1,258.38$ & $\$$ & $1,554.57$ & $\$$ & $2,211.11$ \\
\hline City Portion & $\$ 2,954.35$ & $\$ 3,168.30$ & $\$$ & $3,914.04$ & $\$$ & $5,567.04$ \\
\hline HPTRP Application Fee ${ }^{3}$ & $\$ 100.00$ & $\mathrm{~N} / \mathrm{A}$ & & $\mathrm{N} / \mathrm{A}$ & & $\mathrm{N} / \mathrm{A}$ \\
\hline HPTR (30\%) & $\$ 1,237.66$ & $\$ 1,328.00$ & $\$$ & $1,640.58$ & $\$$ & $2,333.45$ \\
\hline
\end{tabular}

Table 4 - Toronto Residential Condensed

\begin{tabular}{|c|c|c|c|c|c|}
\hline \multicolumn{6}{|c|}{ Residential Home in Penetanguishene } \\
\hline & Year 1 & Year 2 & Year 5 & & Year 10 \\
\hline Property Value $^{1}$ & $\$ 314,000$ & $\$ 319,966.00$ & $\$ 344,985.28$ & & $408,665.73$ \\
\hline $\begin{array}{l}\text { MLS Home Price Index (HPI) } \\
\text { Composite Benchmark }{ }^{1}\end{array}$ & $1.90 \%$ & $1.90 \%$ & $1.90 \%$ & & $1.90 \%$ \\
\hline Property Tax ${ }^{2}$ & $\$ 4,498.38$ & $\$ 4,583.85$ & $\$ \quad 4,942.28$ & $\$$ & $5,854.57$ \\
\hline Education Portion & $\$ 666.31$ & 678.97 & 732.06 & $\$$ & 867.19 \\
\hline City Portion & $\$ 2,225.99$ & $\$ \quad 2,268.29$ & $\$ \quad 2,445.65$ & $\$$ & $2,897.09$ \\
\hline County Portion & $\$ 961.11$ & 979.37 & $\$ 1,055.95$ & $\$$ & $1,250.87$ \\
\hline OPP Portion & $\$ 645.60$ & 657.86 & 709.30 & $\$$ & 840.23 \\
\hline HPTRP Application Fee ${ }^{3}$ & $\$ 100.00$ & $N / A$ & $\mathrm{~N} / \mathrm{A}$ & & $\mathrm{N} / \mathrm{A}$ \\
\hline HPTR (40\%) & $\$ 1,156.92$ & $\$ 1,178.90$ & $\$ \quad 1,271.08$ & $\$$ & $1,505.71$ \\
\hline
\end{tabular}

Table 5 - Penetanguishene Residential Condensed

The reason the property owner in Penetanguishene pays more in property tax, yet receives less in HPTR is due to the fact that tax relief only applies to the lower tier and education portions of property tax. Therefore, the portion of property tax that goes to the upper tier (county) and the OPP in this example is not calculated as part of the HPTR total. On the other hand, the hypothetical properties in Toronto and Peterborough receive HPTR on the total amount of property tax they pay, as both are in 
single tier municipalities where property tax is composed of the city and education portions exclusively. As such, I recommend that the HIG makes up the difference in lower tier municipalities. This would treat all properties enrolled in a HPTRP uniformly, regardless of whether they are located in a single or lower tier municipality. In other words, it would emulate tax relief provided in a single tier municipal scenario to property owners located in multi-tiered jurisdictions. Therefore, owners of historic properties across Ontario could rely on receiving a uniform benefit - anywhere between $10 \%$ and $40 \%$ off of the total property tax they pay annually. Applying my recommendation to the Penetanguishene scenario changes the yearly net value figures from negative to positive. 


\begin{tabular}{|c|c|c|c|c|c|}
\hline \multicolumn{6}{|c|}{ Residential Home in Penetanguishene } \\
\hline & Year 1 & Year 2 & Year 5 & & Year 10 \\
\hline Property Value $^{1}$ & $\$ 314,000$ & $\$ 319,966.00$ & $\$ 344,985.28$ & & $408,665.73$ \\
\hline $\begin{array}{l}\text { MLS Home Price Index (HPI) } \\
\text { Composite Benchmark }{ }^{1}\end{array}$ & $1.90 \%$ & $1.90 \%$ & $1.90 \%$ & & $1.90 \%$ \\
\hline Property Tax ${ }^{2}$ & $\$ 4,498.38$ & $\$ 4,583.85$ & $\$ \quad 4,942.28$ & $\$$ & $5,854.57$ \\
\hline Education Portion & $\$ 666.31$ & 678.97 & 732.06 & $\$$ & 867.19 \\
\hline City Portion & $\$ 2,225.99$ & $\$ 2,268.29$ & $\$ 2,445.65$ & $\$$ & $2,897.09$ \\
\hline County Portion & $\$ 961.11$ & 979.37 & $\$ 1,055.95$ & $\$$ & $1,250.87$ \\
\hline OPP Portion & $\$ 645.60$ & 657.86 & 709.30 & $\$$ & 840.23 \\
\hline HPTRP Application $\mathrm{Fee}^{3}$ & $\$ 100.00$ & $\mathrm{~N} / \mathrm{A}$ & $N / A$ & & $N / A$ \\
\hline HPTR (40\%) & $\$ 1,156.92$ & $\$ 1,178.90$ & $\$ 1,271.08$ & $\$$ & $1,505.71$ \\
\hline Heritage Incentivization Grant & $\$ 642.43$ & 654.64 & 705.83 & $\$$ & 836.11 \\
\hline Estimated Easement Cost & $\$ 500.00$ & $\mathrm{~N} / \mathrm{A}$ & N/A & & N/A \\
\hline $\begin{array}{l}\text { Estimated Required Upkeep } \\
\text { Costs on Heritage Features, } \\
\text { Per Annum }{ }^{4}\end{array}$ & $\$ 850.00$ & 871.25 & 938.24 & $\$$ & $1,061.53$ \\
\hline $\begin{array}{l}\text { Estimated Increase in Insurance } \\
\text { Premium due to Easement, Per } \\
\text { Annum }{ }^{4}\end{array}$ & $\$ 350.00$ & 358.75 & 395.99 & $\$$ & 448.03 \\
\hline $\begin{array}{l}\text { Yearly Net Value of Enrollment } \\
\text { in HPTRP }\end{array}$ & 0.65 & 603.54 & 642.68 & $\$$ & 832.26 \\
\hline
\end{tabular}

Table 6 - Penetanguishene Residential Using HIG

The intent of this additional CIP is not to provide an additional blanket monetary benefit to all designated properties enrolled in a HPTRP, but to negate the existing financial burdens experienced by some who seek to participate. Ultimately, this HIG program seeks to serve the same ends as the HPTRP: to encourage good stewardship, maintenance and conservation of locally designated heritage properties. However, the former does so by remedying unforeseen shortcomings in the latter. It is envisioned that the two tools, taken together, will provide a fair and enticing financial inducement, so that private citizens, entrepreneurs, and businesses alike would be remiss not to have their property designated. 


\section{Conclusion}

Heritage resources across the Province are under constant threat of deterioration and destruction as a result of the unfortunate fact that it is easier and more cost effective to simply demolish a heritage structure than it is to upgrade and preserve it. Once a heritage structure is demolished, its craftsmanship, its presence and its history are lost forever and that direct connection to our past that exists within every one of these resources can never again be replicated.

While it is acknowledged that the upkeep and betterment of a building is the responsibility of every owner, it is widely recognized that heritage properties may require more intensive care and rehabilitation at a higher cost than those associated with a newer building. This is due to the specialized maintenance often required for an older building. In recognition of society's interest and desire to retain and preserve its heritage resources, there is justification for some form of public program to help assist with the maintenance efforts. It is from this ethos that the Province has allowed municipalities to create HPTRP's. Under certain circumstances these programs have proven useful in spurring revitalization and renovation efforts for heritage properties; however, they have also created a problematic financial scenario that is undermining their very intent. This paper has put forth a recommendation to ameliorate this issue by taking advantage of the complimentary relationship between municipal HPTRP's and CIP's. If successful, existing HPTRP's and the envisioned HIG program together will result in an increase in heritage designations, a revitalized historic building stock and a more robust tax base for local governments. 
Appendix A
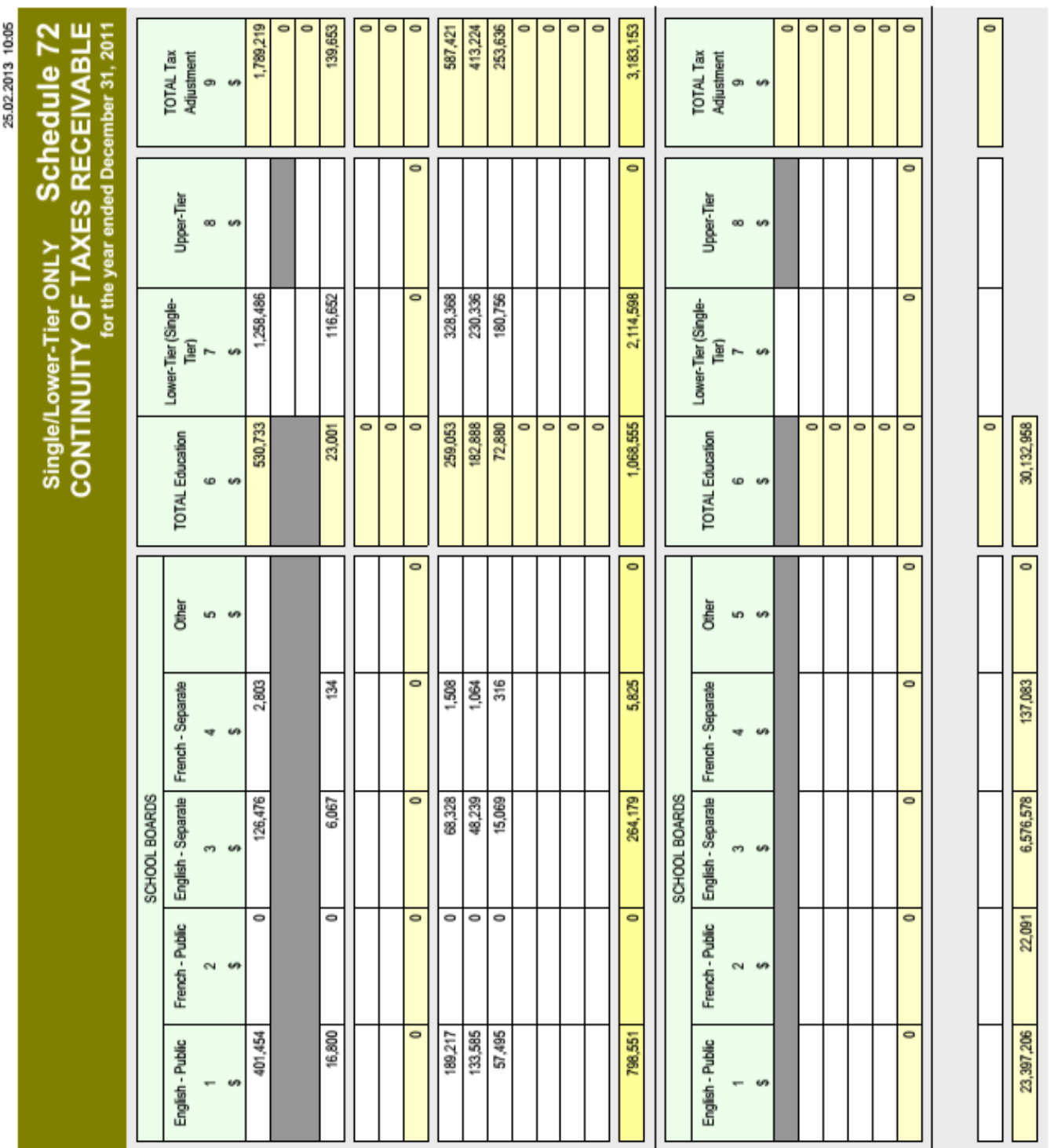

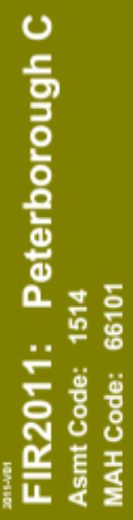
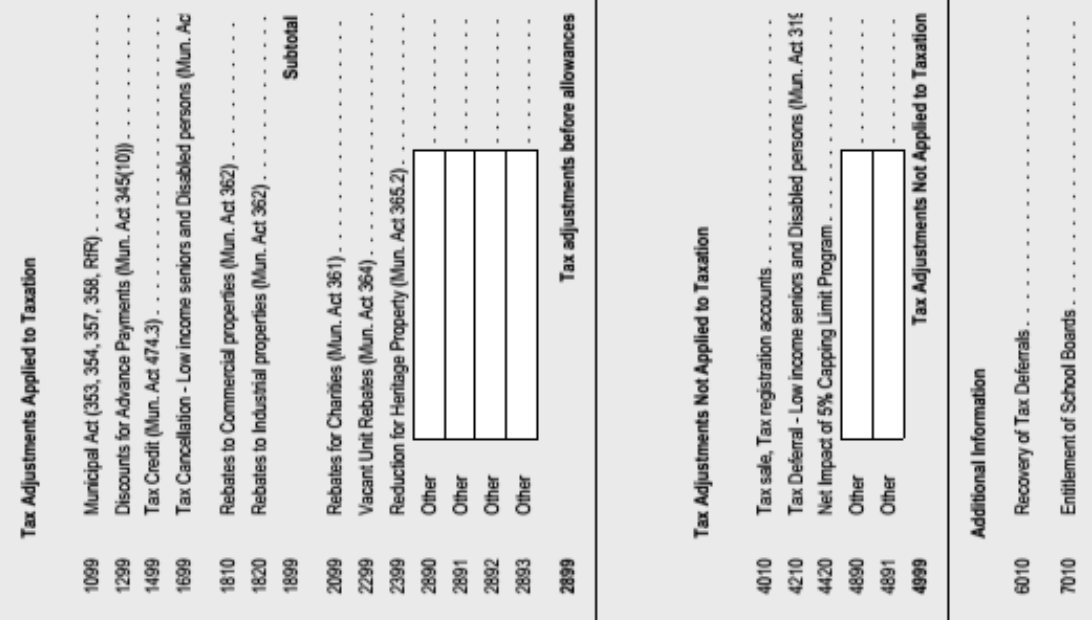


\section{Appendix B}

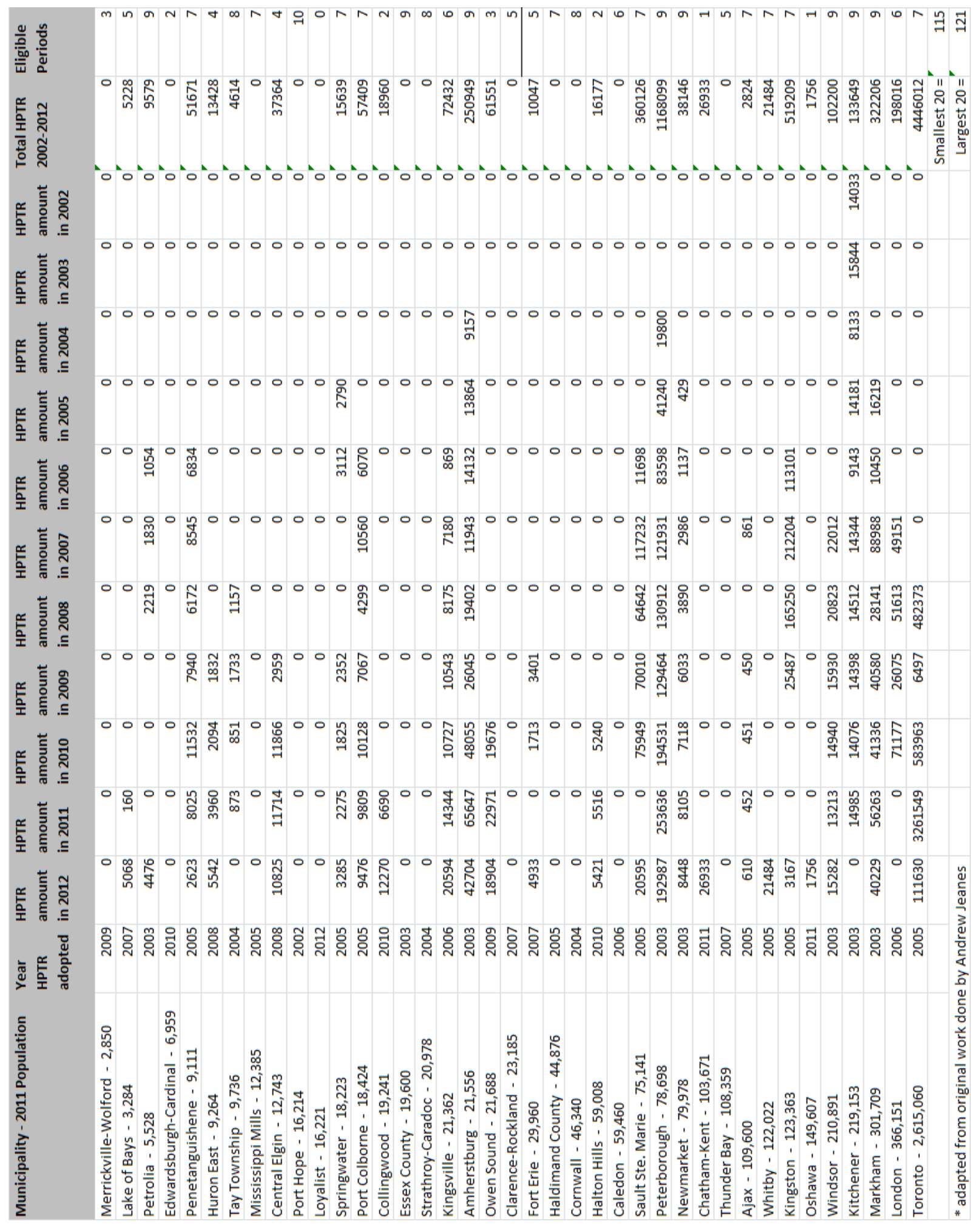




\section{Appendix C}
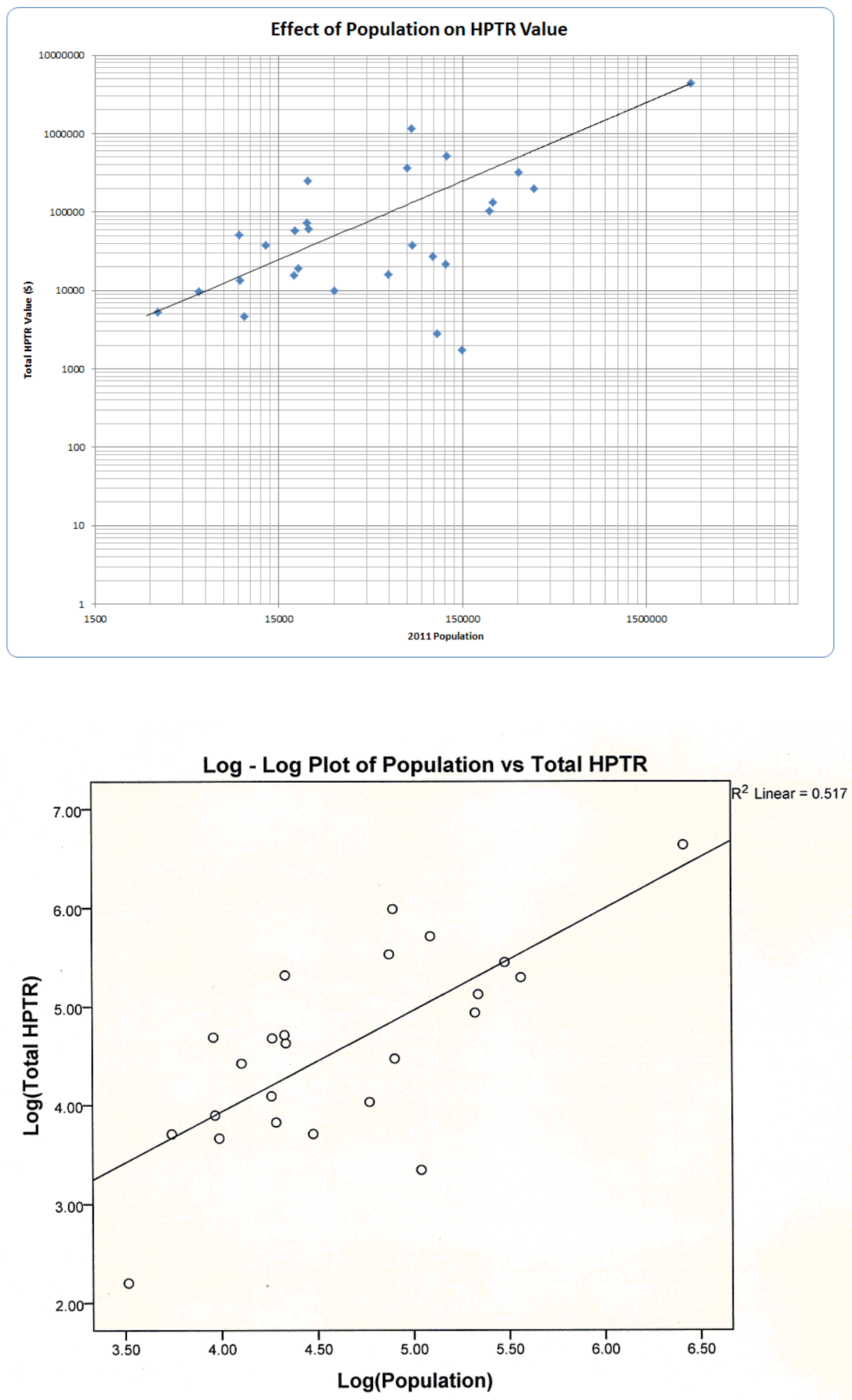


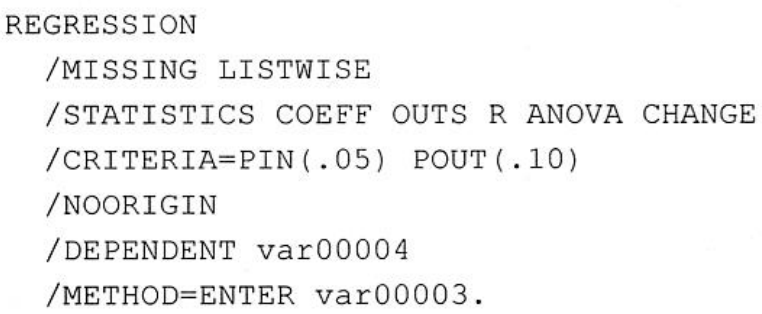

\section{Regression}

[Dataset0]

\begin{tabular}{|l|l|l|l|}
\multicolumn{4}{c|}{ Variables Entered/Removed $^{\mathrm{a}}$} \\
\hline Model & $\begin{array}{c}\text { Variables } \\
\text { Entered }\end{array}$ & $\begin{array}{c}\text { Variables } \\
\text { Removed }\end{array}$ & Method \\
\hline 1 & $\begin{array}{l}\text { Log } \\
\text { (Population) }^{\mathrm{b}}\end{array}$ & & Enter \\
\hline
\end{tabular}

a. Dependent Variable: Log(Total HPTR)

b. All requested variables entered.

\begin{tabular}{|c|c|c|c|c|c|c|c|}
\hline & & & & el Summary & & & \\
\hline \multirow[b]{2}{*}{ Model } & \multirow[b]{2}{*}{$\mathrm{R}$} & \multirow[b]{2}{*}{ R Square } & \multirow[b]{2}{*}{$\begin{array}{c}\text { Adjusted R } \\
\text { Square } \\
\end{array}$} & \multirow[b]{2}{*}{$\begin{array}{l}\text { Std. Error of } \\
\text { the Estimate }\end{array}$} & \multicolumn{3}{|c|}{ Change Statistics } \\
\hline & & & & & $\begin{array}{c}\text { R Square } \\
\text { Change } \\
\end{array}$ & F Change & df1 \\
\hline 1 & $.719^{a}$ & .517 & .495 & .69204 & .517 & 23.578 & 1 \\
\hline
\end{tabular}

\section{Model Summary}

\begin{tabular}{|l|r|r|}
\hline \multirow{2}{*}{ Model } & \multicolumn{2}{|c|}{ Change Statistics } \\
\cline { 2 - 3 } & \multicolumn{1}{|c|}{ df2 } & Sig. F Change \\
\hline 1 & 22 & .000 \\
\hline
\end{tabular}

a. Predictors: (Constant), Log(Population)

\begin{tabular}{|rl|r|r|r|r|r|}
\hline \multicolumn{1}{|c|}{ ANOVA $^{\text {a }}$} \\
Model & & $\begin{array}{l}\text { Sum of } \\
\text { Squares }\end{array}$ & \multicolumn{1}{c|}{ df } & Mean Square & F & Sig. \\
\hline 1 & Regression & 11.292 & 1 & 11.292 & 23.578 & $.000^{\mathrm{b}}$ \\
& Residual & 10.536 & 22 & .479 & & \\
& Total & 21.828 & 23 & & & \\
\hline
\end{tabular}

a. Dependent Variable: Log(Total HPTR)

b. Predictors: (Constant), Log(Population) 


\section{Appendix D}

\begin{tabular}{|c|c|c|c|c|c|c|c|}
\hline \multicolumn{8}{|c|}{ Residential Home in Toronto } \\
\hline & Year 1 & & Year 2 & & Year 5 & & ear 10 \\
\hline Property Value ${ }^{1}$ & $\$ 553,193$ & & $93,576.09$ & & $733,289.66$ & $\$ 1$, & $42,975.66$ \\
\hline $\begin{array}{l}\text { MLS Home Price Index (HPI) } \\
\text { Composite Benchmark }{ }^{2}\end{array}$ & $7.30 \%$ & & $7.30 \%$ & & $7.30 \%$ & & $7.30 \%$ \\
\hline Property Tax ${ }^{2}$ & $\$ 4,125.52$ & $\$$ & $4,426.68$ & $\$$ & $5,468.61$ & $\$$ & $7,778.15$ \\
\hline Education Portion & $\$ 1,173.41$ & $\$$ & $1,258.38$ & $\$$ & $1,554.57$ & $\$$ & $2,211.11$ \\
\hline City Portion & $\$ 2,954.35$ & $\$$ & $3,168.30$ & $\$$ & $3,914.04$ & $\$$ & $5,567.04$ \\
\hline HPTRP Application Fee ${ }^{3}$ & $\$ 100.00$ & & $\mathrm{~N} / \mathrm{A}$ & & $\mathrm{N} / \mathrm{A}$ & & $\mathrm{N} / \mathrm{A}$ \\
\hline HPTR $(30 \%)$ & $\$ 1,237.66$ & $\$$ & $1,328.00$ & $\$$ & $1,640.58$ & $\$$ & $2,333.45$ \\
\hline Estimated Easement Cost & $\$ 500.00$ & & $\mathrm{~N} / \mathrm{A}$ & & $\mathrm{N} / \mathrm{A}$ & & $\mathrm{N} / \mathrm{A}$ \\
\hline $\begin{array}{l}\text { Estimated Required Upkeep } \\
\text { Costs on Heritage Features, } \\
\text { Per Annum }{ }^{4}\end{array}$ & $\$ 850.00$ & $\$$ & 871.25 & $\$$ & 938.24 & $\$$ & $1,061.53$ \\
\hline $\begin{array}{l}\text { Estimated Increase in Insurance } \\
\text { Premium due to Easement, Per } \\
\text { Annum }{ }^{4}\end{array}$ & $\$ 350.00$ & $\$$ & 358.75 & $\$$ & 395.99 & $\$$ & 448.03 \\
\hline $\begin{array}{l}\text { Yearly Net Value of Enrollment } \\
\text { in HPTRP }\end{array}$ & -\$ 562.34 & $\$$ & 98.00 & $\$$ & 306.35 & $\$$ & 823.88 \\
\hline \multicolumn{8}{|c|}{$\begin{array}{l}{ }^{1} \text { based on data from Toronto Real Estate Board - } \\
\text { http://www.torontorealestateboard.com/market_news/market_watch/ }\end{array}$} \\
\hline \multicolumn{8}{|c|}{$\begin{array}{l}{ }^{3} \text { based on City of Toronto data - } \\
\text { http://www1.toronto.ca/wps/portal/contentonly?vgnextoid=08e20621f3161410VgnVCM10000071d } \\
60 f 89 \text { RCRD\&vgnextchannel=6208036318061410VgnVCM10000071d60f89RCRD }\end{array}$} \\
\hline${ }^{4}$ increased based on current inflation & rate $(2.5 \%)$ - & & ://www.ba & & fcanada.ca/ & & \\
\hline
\end{tabular}




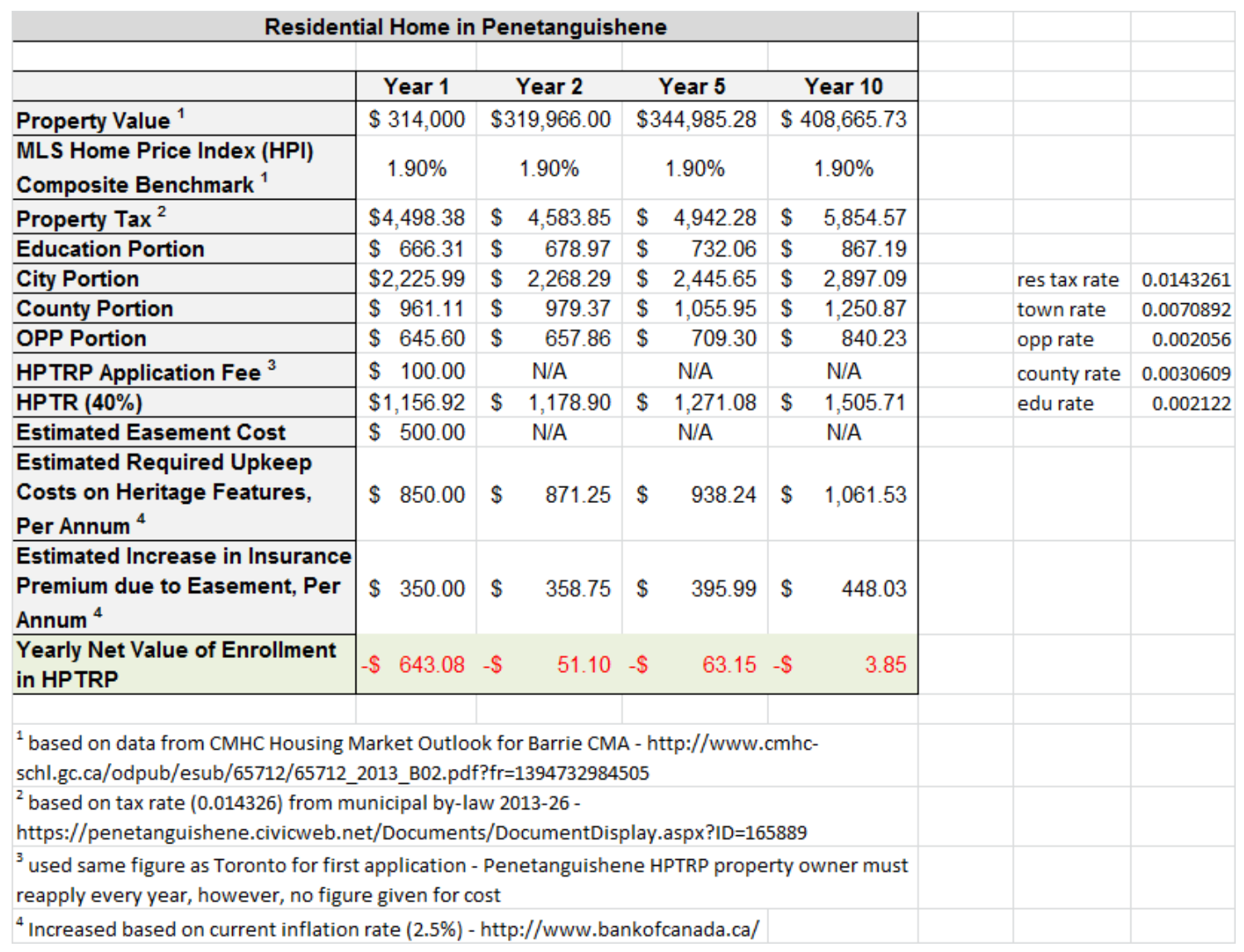

\begin{tabular}{|c|c|c|c|c|c|c|}
\hline \multicolumn{5}{|c|}{ Commercial Property in Peterborough } & & \\
\hline & Year 1 & Year 2 & Year 5 & Year 10 & & \\
\hline Property Value $^{1}$ & $\$ 578,000$ & $\$ 614,760.80$ & $\$ 786,718.72$ & $\$ 1,370,327.71$ & & \\
\hline $\begin{array}{l}\text { Average Annual Growth for } \\
\text { Commercial Properties }^{1}\end{array}$ & $6.36 \%$ & $6.36 \%$ & $6.36 \%$ & $6.36 \%$ & & \\
\hline Property Tax ${ }^{2}$ & $\$ 14,493.08$ & $\$ 15,414.84$ & $\$ 19,726.60$ & $34,360.32$ & & \\
\hline Education Portion & $\$ 1,225.36$ & $\$ \quad 1,303.29$ & $\$ \quad 1,667.84$ & $2,905.09$ & multi-res tax rate & $2.51 \%$ \\
\hline City Portion & $\$ 13,267.72$ & $\$ 14,111.55$ & $\$ 18,058.76$ & $31,455.23$ & city rate & $2.30 \%$ \\
\hline HPTRP Application Fee ${ }^{3}$ & $\$ \quad 100.00$ & $\mathrm{~N} / \mathrm{A}$ & $\mathrm{N} / \mathrm{A}$ & $\mathrm{N} / \mathrm{A}$ & edu rate & $0.21 \%$ \\
\hline HPTR $(20 \%)$ & $\$ 2,898.62$ & $\$ \quad 6,165.94$ & \$ $7,890.64$ & $13,744.13$ & & \\
\hline Estimated Easement Cost & $\$ \quad 500.00$ & N/A & $\mathrm{N} / \mathrm{A}$ & $\mathrm{N} / \mathrm{A}$ & & \\
\hline $\begin{array}{l}\text { Estimated Required Upkeep } \\
\text { Costs on Heritage Features, } \\
\text { Per Annum }{ }^{4}\end{array}$ & $\$ 1,500.00$ & $\$ \quad 1,537.50$ & $\$ \quad 1,655.72$ & $1,873.29$ & & \\
\hline $\begin{array}{l}\text { Estimated Increase in Insurance } \\
\text { Premium due to Easement, Per } \\
\text { Annum }^{4}\end{array}$ & $\$ 750.00$ & 768.75 & 848.56 & 960.06 & & \\
\hline $\begin{array}{l}\text { Yearly Net Value of Enrollment } \\
\text { in HPTRP }\end{array}$ & 48.62 & $\$ \quad 3,859.69$ & $\$ \quad 5,386.37$ & $10,910.77$ & & \\
\hline \multicolumn{7}{|c|}{$\begin{array}{l}{ }^{1} \text { calculated property value based on data provided in staff report and growth rate provided (it's the } \\
\text { average annual growth for commercial properties in core area between } 2003 \text { and } 2009 \text { - } \\
\text { http://www.peterborough.ca/Assets/City+Assets/Arts\$!2c+Culture+\$!26+Heritage/Documents/HPTR } \\
\text { P+Review.pdf }\end{array}$} \\
\hline \multicolumn{7}{|c|}{$\begin{array}{l}{ }^{2} \text { based on } 2013 \text { tax rate for multi-residential }(2.5074530 \%) \text { - } \\
\text { http://www.peterborough.ca/Assets/City+Assets/Property+Tax/Documents/Tax+Bill+Inserts/2013+- }\end{array}$} \\
\hline \multicolumn{2}{|c|}{${ }^{3}$ used same figure as Toronto for first application } & & & & & \\
\hline \multicolumn{5}{|c|}{${ }^{4}$ Increased based on current inflation rate (2.5\%) - http://www.bankofcanada.ca/ } & & \\
\hline
\end{tabular}




\begin{tabular}{|c|c|c|c|c|c|c|}
\hline \multicolumn{5}{|c|}{ Residential Home in Penetanguishene } & & \\
\hline & Year 1 & Year 2 & Year 5 & Year 10 & & \\
\hline Property Value ${ }^{1}$ & $\$ 314,000$ & $\$ 319,966.00$ & $\$ 344,985.28$ & $\$ 408,665.73$ & & \\
\hline $\begin{array}{l}\text { MLS Home Price Index (HPI) } \\
\text { Composite Benchmark }{ }^{1}\end{array}$ & $1.90 \%$ & $1.90 \%$ & $1.90 \%$ & $1.90 \%$ & & \\
\hline Property Tax ${ }^{2}$ & $\$ 4,498.38$ & $\$ 4,583.85$ & $\$ \quad 4,942.28$ & $\$ \quad 5,854.57$ & & \\
\hline Education Portion & $\$ 666.31$ & 678.97 & 732.06 & 867.19 & & \\
\hline City Portion & $\$ 2,225.99$ & $\$ \quad 2,268.29$ & $\$ 2,445.65$ & $\$ \quad 2,897.09$ & res tax rate & 0.01432605 \\
\hline County Portion & $\$ 961.11$ & 979.37 & $\$ 1,055.95$ & $\$ \quad 1,250.87$ & town rate & 0.00708915 \\
\hline OPP Portion & $\$ 645.60$ & 657.86 & $\$ \quad 709.30$ & 840.23 & opp rate & 0.00205604 \\
\hline HPTRP Application Fee ${ }^{3}$ & $\$ 100.00$ & N/A & $\mathrm{N} / \mathrm{A}$ & $\mathrm{N} / \mathrm{A}$ & county rate & 0.00306086 \\
\hline HPTR (40\%) & $\$ 1,156.92$ & $\$ \quad 1,178.90$ & $\$ \quad 1,271.08$ & $\$ \quad 1,505.71$ & edu rate & 0.002122 \\
\hline Heritage Incentivization Grant & $\$ 642.43$ & 654.64 & $\$ \quad 705.83$ & 836.11 & & \\
\hline Estimated Easement Cost & $\$ 500.00$ & $\mathrm{~N} / \mathrm{A}$ & $\mathrm{N} / \mathrm{A}$ & N/A & & \\
\hline $\begin{array}{l}\text { Estimated Required Upkeep } \\
\text { Costs on Heritage Features, } \\
\text { Per Annum }{ }^{4}\end{array}$ & $\$ 850.00$ & 871.25 & 938.24 & $\$ \quad 1,061.53$ & & \\
\hline $\begin{array}{l}\text { Estimated Increase in Insurance } \\
\text { Premium due to Easement, Per } \\
\text { Annum }{ }^{4}\end{array}$ & $\$ 350.00$ & 358.75 & 395.99 & 448.03 & & \\
\hline $\begin{array}{l}\text { Yearly Net Value of Enrollment } \\
\text { in HPTRP }\end{array}$ & 0.65 & 603.54 & 642.68 & 832.26 & & \\
\hline \multicolumn{7}{|c|}{$\begin{array}{l}{ }^{1} \text { based on data from CMHC Housing Market Outlook for Barrie CMA - http://www.cmhc- } \\
\text { schl.gc.ca/odpub/esub/65712/65712_2013_B02.pdf?fr=1394732984505 }\end{array}$} \\
\hline \multicolumn{7}{|c|}{$\begin{array}{l}{ }^{2} \text { based on tax rate }(0.014326) \text { from municipal by-law } 2013-26 \text { - } \\
\text { https://penetanguishene.civicweb.net/Documents/DocumentDisplay.aspx?ID=165889 }\end{array}$} \\
\hline \multicolumn{7}{|c|}{$\begin{array}{l}{ }^{3} \text { used same figure as Toronto for first application - Penetanguishene HPTRP property owner must } \\
\text { reapply every year, however, no figure given for cost }\end{array}$} \\
\hline${ }^{4}$ Increased based on current inflation & rate $(2.5 \%)$ - & http://www.ba & kofcanada.ca/ & & & \\
\hline
\end{tabular}




\section{Bibliography}

Asabere, P.K., Hachey, G. and Grubaugh, S. (1989) Architecture, Historic Zoning, and the Value of Homes, Journal of Real Estate Finance and Economics, 2, pp. 181195.

Asabere, P.K. and Huffman, F.E. (1994a) Historic Designation and Residential Market Values, The Appraisal Journal, 62(3), pp. 396--401.

Asabere, P.K. and Huffman, F.E. (1994b) The Values Discounts Associated with Historic Facade Easements, The Appraisal Journal, 62(2), pp. 270-277.

Ascroft, S. (2004, Spring). What's your policy? Owners face insurance woes on older homes. Heritage: The Magazine of the Heritage Canada Foundation, Retrieved from http://www.heritagecanada.org/sites/www.heritagecanada.org/files/What's Your Policy_EN.pdf

Ashworth, G.J. (2002) Conservation Designation and the Revaluation of Property: the risk of heritage innovation, International Journal of Heritage Studies, 8(1), pp 9-23.

Benson, V.O. and Klein, R. (1988) The Impact of Historic Districting on Property Values, The Appraisal Journal, 56(2), pp. 223-232.

Canning \& Pitt Associates, Inc and Sheppard Case Architects Inc. Background report No. 3. Economic Benefits of Built Heritage Revival. Downtown St. John's Strategy for Economic Development and Heritage Preservation. April 12, 2000.

City of Markham. Heritage Department, (2013). Heritage property tax reduction program information brochure - 2013 tax year. Retrieved from website: https://www.markham.ca/wps/wcm/connect/markhampublic/220f8205-dfc8-4a8bbf5b-44effacbc7d0/Brochure Tax Year 2013.pdf?MOD=AJPERES\&CACHEID=220f8205-dfc8-4a8b-bf5b-44effacbc7d0

City of Peterborough. Department of Community Services. (2011). A review of the effectiveness of the heritage property tax relief program(CSACH11-007). Retrieved from website: http://www.peterborough.ca/Assets/City Assets/Arts $\$$ !2c Culture \$!26 Heritage/Documents/HPTRP Review.pdf

City of Toronto. (2007). Council adoption of proposed Section 37 implementation guidelines. Retrieved from website: http://www.toronto.ca/legdocs/mmis/2007/pg/bgrd/backgroundfile-2441.pdf 
Clarion Associates. (2002). Investing in Michigan's future: The economic benefits of historic preservation. Retrieved from

http://www.michigan.gov/documents/hal_mhc_shpo_econ_benies_115616_7.pdf

Coulson, N.E. and Leichenko, R.M. (2004) Historic Preservation and Neighbourhood Change, Urban Studies, 41(8), pp. 1587-1600.

Coulson, N.E. and Leichenko, R.M. (2001) The Internal and External Impact of Historical Designation on Property Values, Journal of Real Estate Finance and Economics, 23(1), pp. 113-124.

Goddard-Bowman, R. 2003. Something Old is Something New: The Role of Heritage Preservation in Economic Development. Papers in Canadian Economic Development. Volume 9. Economic Development Program, University of Waterloo. P.122.

Kovacs, J.F., Shipley, R. Snyder, M. and Copeland, S. (2008) Do Heritage Conservation Districts Work? the case of Kitchener's Upper Doon District, Canadian Journal of Urban Research, 17(2), pp 125-141.

Leichenko, R.M., Coulson, E. and Listokin, D. (2001) Historic Preservation and Residential Property Values: an analysis of Texas Cities, Urban Studies, 38(11), pp. 1973-1987.

Lennox, C. and Revels, J. (2002) The Economic Benefits of Historic Preservation in South Carolina, South Carolina Department of Archives and History, Columbia, South Carolina, US.

Listokin, D. (1985) The Appraisal of Designated Historic Properties, The Appraisal Journal, 53(2), pp. 200-217.

Lockard, W.E. and Hinds, D. (1983) Historic Zoning Considerations in Neighbourhood and District Analysis, The Appraisal Journal, 51(4), pp. 485-498.

Ministry of Municipal Affairs and Housing (MMAH), Provincial Planning Policy Branch. 2009. Height and density bonusing (s. 37). Building Blocks for Sustainable Planning 5. Toronto: Queen's Printer for Ontario.

OMTC (2006) Heritage Resources in the Land Use Planning Process - Ontario Heritage Tool Kit, Ontario Ministry of Tourism and Culture, Government of Canada, Queen's Printer for Ontario, Canada.

Province of Ontario. Ministry of Municipal Affairs and Housing. (2008). Community improvement planning handbook 2008. Retrieved from website: http://www.mah.gov.on.ca/Page1297.aspx 
Province of Ontario. Ministry of Municipal Affairs and Housing. (2005). Getting started: Heritage property tax relief. Retrieved from website:

http://www.mtc.gov.on.ca/en/publications/taxguide-e.pdf

Rypkema, D. (1994) The Economics of Historic Preservation, National Trust for Historic Preservation, Washington DC, US.

Schaeffer, P. and Millerick, C.A. (1991) The Impact of Historic District Designation on Property Values: An Empirical Study, Economic Development Quarterly, 5(4), pp. 301-312.

Shipley, R. (2008) Getting Heritage Development Right, Municipal World, 118(2), pp.1314.

Shipley, R .(2007) The Real Impact of Heritage Designation, Municipal World, 117(2), pp. 9-12.

Shipley, R. (2000) Heritage Designation and Property Values: is there an effect? International Journal of Heritage Studies, 6(1), pp 83-100. 